A RCHIWA, BIBLIOTEKI

I MUZEA KOŚCIELNE 109 (2018)

https://doi.org/10.31743/abmk.2018.109.06

SEBASTIAN DUDZIK* - TORUŃ

\title{
THEATRUM URBIUM ITALICARUM PIETRA BERTELLEGO - PRZEDSIEWZIECIE WYDAWNICZE BISKUPA HIERONIMA ROZRAŻEWSKIEGO PODCZAS JEGO PODRÓŻY DO RZYMU
}

Z końcem 1599 roku w Wenecji ukazała się niewielkich rozmiarów, bogato ilustrowana książka Theatrum urbium Italicarum. Jej autorem oraz wydawcą był padewski drukarz i rytownik - Pietro Bertelli ${ }^{1}$. Charakter publikacji określa świetnie już sam jej tytuł. Przedstawienie miast włoskich to książka sytuująca się w dosyć licznej grupie XVI i XVII wiecznych pozycji o charakterze geograficznym lub przewodnikowo-topograficznym ${ }^{2}$. Zawiera krótkie, dwu lub trzystronicowe charakterystyki pięćdziesięciu siedmiu miast włoskich wzbogacone ich rytowanymi, całostronicowymi widokami.

Zgodnie z zawartym we frontyspisie herbem i tytułową inskrypcją Bertelli ofiarował tę książkę biskupowi kujawsko-pomorskiemu Hieronimowi Rozrażewskiemu (il. 1). Potwierdza to również obszerna dedykacja, w której znaleźć można delikatną sugestię o bezpośrednim zaangażowaniu polskiego hierarchy w jej powstanie.

Wśród wielu szesnastowiecznych literackich i bibliofilskich poloników Theatrum może nie jest przedsięwzięciem najefektowniejszym ani najwybitniejszym pod względem artystycznym, niemniej stanowi istotny i zarazem mało poznany przykład polsko-włoskich kontaktów kulturalnych i intelektualnych w czasach nowożytnych. W polskiej literaturze, oprócz przywołania samego tytułu w kontekście publikacji dedykowanych biskupowi Rozrażewskiemu oraz reprodukcji

* Sebastian Dudzik - dr historii sztuki; adiunkt w Katedrze Historii Sztuki i Kultury; Instytut Sztuki UMK w Toruniu; e-mail: sebdudzik@op.pl

${ }^{1}$ Por. F. Borroni, Bertelli Pietro, w: Dizionario Biografico degli Italiani, t. 9, Roma 1967, s. 499-500; E. Filippi, Bertelli Pietro, w: K.G. Saur, Allgemeines Künstlerlexikon, t. 10, Leipzig 1995 s. 50; G.M. Mazzuchelli, Gli Scrittori d'Italia, T. 2, Brescia 1760, s. 136; G. Zappella, Le marche dei tipografi e degli editori italiani del Cinquecento, T. 1, Milano 1986.

${ }^{2}$ Do tego typu publikacji należą choćby kolejne tomy Civitates Orbis terrarum Georga Brauna i Fransa Hogenberga, czy wydane w Wenecji w 1568 roku Civitatum aliquod insigniorum et locorum magis munitorum exacta delineatio Ferrando Bertellego. 
frontyspisu zamieszczonej w monografii poświęconej polsko-włoskim związkom umysłowo-kulturalnym autorstwa Tadeusza Ulewicza, brakuje jakiejkolwiek głębszej refleksji na temat specyfiki i znaczenia tej książki³ . W nielicznych lakonicznych charakterystykach pominięto zupełnie problem ewentualnych powiązań oficyny Bertellego z adresatem dedykacji - biskupem Hieronimem Rozrażewskim. Za istnieniem takowych przemawia choćby fakt, że czas wydania Theatrum... zbiegł się z podróżą polskiego dostojnika na Wielki Jubileusz 1600 roku do Rzymu, a o jego rozlicznych wcześniejszych kontaktach z wydawcami włoskimi świadczą odnotowane w księgozbiorze publikacje oficyn wydawniczych z Rzymu, Bazylei czy Wenecji ${ }^{4}$.

Również w obcojęzycznej literaturze poświeconej graficznemu obrazowaniu miast $\mathrm{w}$ czasach nowożytnych problem publikacji Bertellego pojawia się sporadycznie. $\mathrm{Z}$ rzadka Theatrum wzmiankowane było w kontekście ikonografii widoków większych włoskich miast jak: Rzym, Wenecja czy Padwas. Jedyną publikacją obszerniej traktującą problem specyfiki sposobów obrazowania miast zamieszczonych w Theatrum jest artykuł Marii Paoli Marabotto z $2011 \mathrm{roku}^{6}$. Referując w nim poznawczy charakter graficznych miast Autorka zwróciła uwagę na specyfikę obrazowania dwóch podstawowych typów ujęcia z perspektywy lotu ptaka.

Nieco szersze omówienie znalazł natomiast dobór i porządek jej merytorycznej zawartości. Niestety również tutaj badania nad publikacją mają charakter kontekstowy i prowadzone były w zasadzie jednopłaszczyznowo. Problem specyfiki prezentowanych $\mathrm{w}$ Theatrum materiałów pojawia się jako wątek uzupełniający w rozważaniach na temat kontaktów między Pietro Bertellim i jego rodziną, a augustiańskim biskupem Angelo Rocca - miłośnikiem oraz znawcą włoskiej

${ }^{3}$ Pozycja ta wymieniona została przez Karola Estreichera w bibliografii staropolskiej, wzmiankowali ją też badacze działalności bpa H. Rozrażewskiego: Paweł Czaplewski, Stanisław Librowski, Ludwik Grzebień oraz Halina Kowalska. Por. P. Czaplewski, Korespondencja biskupa Hieronima Rozrażewskiego, t. 2, Toruń 1939, s. LXI; K. Estreicher, Bibliografia staropolska, t. 26, Kraków 1915, s. 410; L. Grzebień, Biblioteka biskupa Hieronima Rozrażewskiego (1542-1600), „Archiwa, Biblioteki i Muzea Kościelne"(dalej: ABMK), 22 (1971) s. 86-87; S. Librowski, Biskup Hieronim Rozrażewski jako humanista i mecenas, ABMK, 11 (1965) s. 201-263; H. Kowalska, Rozdrażewski Hieronim, w: Polski Stownik Biograficzny, t. 32, Kraków 1991,s. 355-365; T. Ulewicz, Iter Romano-Italicum Polonorum. Czyli o zwiazkach umystowo-kulturalnych Polski z Włochami w wiekach średnich i renesansie, Kraków 1999, il. 62.

${ }^{4}$ Grzebień, Biblioteka biskupa Hieronima Rozrażewskiego, s. 86-87.

${ }^{5}$ Informacje o pojedynczych rycinach publikowane były w pracach poświęconych ikonografii poszczególnym miast włoskich. Por. Le Piante di Roma, red A.P. Frutaz, Roma 1962, tab. 279; J. Schultz, The printed plans and Panoramic Vievs of Venice (1486-1797), Firenze 1970, s. 31; L. Puppi, M. Universo, Le citta nella storia d'Italia. Padova, Bari 1982, s.109.

${ }^{6}$ M.P. Marabotto, In viaggio per conoscere, rappresentare e conserware ritratti di citta' nell "Theatrum Urbium Italicarum", w: C. Gambardella, Le Vie dei Mercanti. S.A.V.E. Heritage. Safeguard, of Architectural Visual, Environmental Heritage, vol. 1, Napoli 2011 (publikacja na CD dostępna również online: http://www.academia.edu/2335712/In_viaggio_per_conoscere_rappresentare_e_conservare._Ritratti_di_citt\%C3\%A0_nel_Theatrum_Urbium_Italicarum_Travel_to_learn_represent_and_store._ City_portraits_in_Theatrum_Urbium_Italicarum (dostęp: 19.06.2016). 
geografii. Pierwsze dywagacje na ten temat poczyniły już w 1991 roku Paola Munafò oraz Nicoletta Muratore ${ }^{7}$. Punktem wyjścia do powiązania obu postaci było odkrycie w jednym z dwóch posiadanych przez hierarchę egzemplarzy Theatrum rękopiśmiennego kwestionariusza do planowanego wydania Brieve descrittione de le città d'Italia e de le terre. Adresatami poczynionych przez Rocco wskazówek byli inni włoscy augustianie. Wklejenie dokumentu do egzemplarza książki naprowadziło badaczki na trop wcześniejszych powiązań dostojnika ze środowiskiem weneckich wydawców. Stosunkowo niedawno wątek ten powrócił w akademickich wykładach Cosimo Damiano Fonseca oraz w obszernym artykule Marii Idy Gulletty poświęconym rysunkowym wedutom z lat 80 . XVI w. autorstwa Rocco8.

Brak solidnych wielopłaszczyznowych opracowań na temat omawianej publikacji Bertellego pozostawia wiele kwestii otwartych. Szerszego i bardziej gruntownego omówienia wymaga zarówno sama zawartość ilustracyjna książki, jak i okoliczności jej powstania, czy ewentualna rola sprawcza polskiego biskupa. W pierwszym z wymienionych obszarów niezwykle istotnym będzie rozpoznanie stylistyczne oraz typologiczne poszczególnych „portretów” miast. Pozwoli ono nie tylko wskazać ich ikonograficzne pierwowzory czy bezpośrednie inspiracje. Umożliwi przede wszystkim precyzyjniejsze określenie kontekstu powstania publikacji, pozwoli na pełniejszą charakterystykę środowiska, w którym to dzieło powstało, umożliwi wreszcie ustalenie jej rzeczywistej wartości tak dla historii szesnastowiecznego włoskiego drukarstwa, jak i polsko-włoskich kontaktów kulturowych oraz artystycznych.

\section{Krótka charakterystyka publikacji ${ }^{9}$}

Omawiana książka opublikowana została w formacie in ottavo ${ }^{10}$. Liczy sobie 102 numerowane karty zawierające kolejno: bogaty rytowany frontyspis, trzystronicowy tekst dedykacyjny, dwie strony spisu treści, 97 kart zawierających opisy i rytowane widoki 57 miast Italii wraz z aneksem oraz rekonstrukcją Starożytne-

${ }^{7}$ N. Muratore, P. Munafò, Immagini di città raccolte da un frate agostiniano alla fine del XVI secolo, Roma 1991, s. 20-22.

${ }^{8}$ C.D. Fonseca, "Che tutto si stamperà in brieve tempo". Un Atlante di Città del Mezzogiorno progettato nel XVI secolo, w: http://www.lincei.it/files/documenti/LectioBrevis_Fonseca_08-02-2013. pdf_(dostęp: 19.06.2016); M.I. Gulletta, Città 'ritratte' per un viaggio in Sicilia alla fine del XVI secolo (Disegni raccolti da P. Angelo Rocca, 1584), w: Viaggio in Sicilia: racconti, segni e città ritrovate. X Convegno di Studi di Sicilia Antica, Caltanissetta 10-11 maggio 2013, red. M. Congiu, C. Micciché, S. Modeo, Caltanissetta-Roma 2014, s. 352-354.

${ }^{9}$ Autorowi artykułu znanych jest kilkanaście zachowanych egzemplarzy dzieła Bertellego. Najwięcej z nich udało się zlokalizować w bibliotekach włoskich (m.in. Rzym, Mediolan, Wenecja, Padwa, Florencja, Genua). W zbiorach polskich, obok obiektu znajdującego się w prywatnych rękach, udało się zlokalizować jedynie niekompletny egzemplarz (brak jednej karty) ze zbiorów Biblioteki Jagiellońskiej Uniwersytetu Jagiellońskiego w Krakowie (Nr inw. Cimelia Q 5642).

${ }^{10}$ Wymiary oprawionej w skórzaną okładkę książki to ok. 250×180 milimetrów. 
go Rzymu. Na rewersie ostatniej karty zamieszczony został kolofon z adresem wydawcy ${ }^{11}$.

Verso pierwszej karty zdobi całostronicowy, miedziorytniczy frontyspis w formie rozbudowanego kartusza okuciowego (il. 1). Centralną jego część stanowi obwiedziona girlandami oraz flankowana maskami prostokątna tablica z inskrypcją: THEATRUM / URBIUM / ITALICARUM / Collectore Petro Bertellio Patau. / Ad Illum et Rev'mum D. D. / Hieronymum Comitem a Rozrazew / Episcopum Vladislaviensi et Pomeraniae / Regni Poloniae Senatorum. W jej zwieńczeniu znajduje się flankowany przez dwa skrzydlate putta mniejszy kartusz z kapeluszem biskupim i herbem Rozrażewskiego - Doliwą. Dolna część kartusza tworzy formę skomplikowanego fartucha z podwieszonymi girlandami oraz dwoma umieszczonymi centralnie nad sobą medalionami: górny $-\mathrm{z}$ wyobrażeniem archanioła Gabriela - znakiem oficyny Pietra Bertellego; dolny natomiast z napisem Venetiis. 1599. Na drugiej i trzeciej karcie książki znajduje się poświęcony Rozrażewskiemu tekst dedykacyjny [aneks a, b]. Pozostała część publikacji podzielona została według spisu treści na 58 rozdziałów, z których każdy poświęcono odrębnemu miastu Italii, z wyjątkiem zamieszczonego na dwudziestej drugiej karcie opisu wyspy Malty oraz zamykającej publikację rekonstrukcji antycznego Rzymu. Krótkiemu tekstowi, zazwyczaj dwu lub trzystronicowemu, towarzyszy zawsze miedziorytnicza weduta. Zdecydowana większość opisów jest przedrukiem tekstów z pięciu wydanych do 1598 roku tomów Civitatis Orbis Terrarum Georga Braun i Franza Hogenberga ${ }^{12}$. Nieliczne wyjątki stanowią passusy dodane autorsko przez Bertellego. Do takich zaliczyć należy krótki akapit kończący opis Parmy.

Przedstawienie włoskich miast rozpoczyna grupa największych i najbardziej znaczących grodów. W kolejności są to: Rzym, Wenecja, Mediolan, Neapol, Florencja, i Genua. Na kolejną grupę składają się cztery miasta sycylijskie: Palermo, Messyna, Catania i Trappani. Dalej prezentowane są mniejsze miejscowości, bez jakiegoś czytelnego klucza topograficznego czy historycznego. Są to kolejno: Trydent, Malta, Cagliari, Turyn, Parma, Piacenza, Cremona, Bolonia, Mantua, Reggio, Ferrara, Pavia, Mirandola, Lucca, Siena, Perugia, Viterbo, Rimini, Sulmona, Netuno, Fano, Urbino, Udine, Treviso, Palma Nuova, Vittorio Veneto (oryg. Seraval), Padwa, Wicenza, Werona, Brescia, Bergamo, Crema, Arcevia (oryg. Rocca Contrada) Orvieto, Aqua Pendente, Ancona, Loreto (oryg. Laurentum) Nceia, Gaeta (oryg. Mola), Velletri (oryg. Belitri), Maddaloni (oryg. Calatia) Pozzuoli (oryg. Puteolanum), Terracina, Tivoli, Galiopolis, Fondi, Taranto (oryg. Tarentum).

Interesujący nas zestaw pięćdziesięciu ośmiu rycin obrazujących włoskie miasta to zbiór bogaty, aczkolwiek nie wyczerpujący repertuaru miejsc godnych odwiedzenia. Rozmieszczenie geograficzne przedstawionych grodów ukazuje dużą dysproporcję między północną częścią Italii (szczególnie terenem Niziny Padań-

${ }^{11}$ Venetiis MDXCIX apud Petrum Bertellium bibliopolam Patavinum.

${ }^{12}$ Interesujące nas tomy dzieła Georga Brauna i Franza Hogenberga ukazywały się kolejno w latach: 1572 (I), 1575 (II), 1581 (III), 1588 (IV), 1598 (V). Ostatni z wymienionych ukazał się już po śmierci Hogenberga. 
skiej) a południową (ryc. 1). W prezentowanej przez Bertellego grupie znalazły się zarówno ośrodki lokalnej władzy, miejsca pielgrzymkowe (Loreto, Catania), jak i miasta leżące wzdłuż najważniejszych szlaków prowadzących do Rzymu. Najbardziej czytelnym traktem jest biegnąca z południa droga, którą niegdyś podróżował cesarz Karol V. ${ }^{13}$ Prowadzi ona z Malty przez sycylijski port Trappano, następnie Palermo, Messynę, Neapol, Fondi, Terracinę Velletri do samego Rzymu. Drugi czytelny szlak biegnie z Francji przez Turyn (bądź Genuę), Lukkę, Florencję, Sienę, Orvieto i Viterbo do Rzymu. Trzeci natomiast z Austrii przez miasta Lombardii i Veneto, Urbino, Perugię i Orvieto także do Wiecznego Miasta.

\section{Wydawca i jego warsztat miedziorytniczy}

Wydawcą Theatrum Urbium Italicarum i prawdopodobnym autorem dużej ilości znajdujących się w niej ilustracji był działający w Padwie oraz Wenecji pomiędzy rokiem 1580 a 1616 edytor, drukarz i miedziorytnik Pietro Bertelli1 ${ }^{14}$. Swe książkowe realizacje opatrywał on najczęściej ujętym w medalion wizerunkiem Gabriela Archanioła oraz sygnaturą Apud Petrum Bertellium Bibliopolam Patavinum. (Taki też znak znajduje się na ostatniej stronie Theatrum). Pietro wywodził się z weneckiej rodziny o bogatych tradycjach drukarskich. Jego krewni - Donato (być może ojciec), Ferrando, Luca oraz Orazio utrzymywali szerokie kontakty z wydawcami i naukowcami całej Europy. Do klientów znanego z publikacji map Donata należał między innymi Abraham Ortelius ${ }^{15}$. To właśnie edycja prac kartograficznych i planów miast przyniosła rodzinie Bertellich największy rozgłos. Współpraca jej członków z Paolem Forlanim i Antonio Lafrerym sprawiła, że zaliczeni zostali do członków tzw. „Szkoły Lafrerego"16. Jak zauważyła Gulletta, rodzina Bertellich pełniła w środowisku weneckim rolę prekursorów i pierwszych popularyzatorów wydań poświeconych miastom i fortecom ${ }^{17}$. Założone przez rodzinę oficyny współpracowały z niemal wszystkimi znaczniejszymi drukarzami i sztycharzami działającymi w Wenecji.

Kształcący się najprawdopodobniej w rodzinnym mieście Pietro na początku lat 80. XVI wieku wyjechał do Padwy, gdzie założył własną oficynę. Przygotowywane przez siebie publikacje wydawał także w pobliskiej Vicenzie oraz Wenecji. Od 1589 roku zajmował się również sztycharstwem. Tworzył zarówno ilustracje książkowe oraz albumowe, jak i reprodukcje znanych dzieł. Przy większych przedsięwzięciach współpracował $\mathrm{z}$ drukarzami, rysownikami i sztycharzami z Wenecji, Mediolanu oraz Vicenzy. Z długiej listy autorów publikujących w jego oficynie wymienić wypada choćby takich jak: Vittorio Zonca, Ottavio Fa-

${ }^{13}$ Por. M.A. Visceglia, Il viaggio ceremoniale di Carlo V dopo Tunisi, w: Dimensioni e problemi della ricerca storica, Roma 2001 s. 5-50.

${ }^{14}$ Por. Przypis nr 1.

${ }^{15}$ R.V. Tooley, Maps in italian Atlases of the Sixtenth Century, „Imago Mundi”, 3 (1939) s. 2930; F. Borroni Salvadori, Carte, piante e stampe storiche delle raccolte lafreriane della Biblioteca Nazionale di Firenze, Rome 1980, s. LXVIII.

${ }^{16}$ F. Borroni Salvadori, s. LXVI-LXIX; S. Scolari Paolo Forlani. w: http://www.mapforum. com/11/11 issue.html (dostęp: 20.07.2007).

${ }^{17}$ Guletta, Città 'ritratte' per un viaggio in Sicilia alla fine del XVI secolo, s. 352. 
bri, Pietro Tomassini, Filippo Gesualdo czy bracia Franz i Andreas Schott (Scotto), o których będzie jeszcze w dalszej części niniejszego tekstu ${ }^{18}$.

Najbardziej znanym dziełem firmowanym przez Pietra Bertellego jest inspirowane wcześniejszym Thesaurum nationum habitus... Alciato Alciato, trzytomowe wydanie Diversarium nationum habitus, zawierające serię tablic z modnymi wówczas kostiumami ${ }^{19}$. Pierwszy tom, dedykowany księciu Reinhardowi von Hannau, ukazał się w Padwie w 1589 roku. Do jego druku użyto klika starszych, pochodzących z Thesaurum..., tablic autorstwa Giacomo Franco ${ }^{20}$. Kolejne tomy ukazały się w 1591 oraz 1594 roku i dedykowano je Wolgangowi von Hutten. O sukcesie przedsięwzięcia świadczy zarówno wydanie kolejnych serii, jak i lokalne naśladownictwa ukazujące się na przełomie szesnastego i siedemnastego wieku $^{21}$.

W 1599 roku wychodzą bardzo popularne w tym czasie Żywoty sułtanów tureckich ze świetnie wykonanymi przez Giorgio Greco (ad instancja Pietro Bertelli) 15 sztychami zawierającymi podobizny Ottomana I i Mohameta III ${ }^{22}$.

Poza wydaniami książkowymi w oficynie Bertellego publikowane były także sztychowane reprodukcje dzieł znanych mistrzów. Do najefektowniejszych należą sztychy dzieł Agostina Carracci (np. Jezus Chrystus i Samarytanka) oraz Tycjana (Św. Matgorzata) ${ }^{23}$.

\section{Problem autorstwa rycin zamieszczonych w książce}

O ile kwestia autorstwa tekstów i osoby wydawcy nie pozostawia wątpliwości, to znacznie bardziej skomplikowanym problemem jest ustalenie autorów poszczególnych ilustracji oraz ich ikonograficznych pierwowzorów. Niejednorodny charakter materiału ilustracyjnego, zarówno pod względem konwencji obrazowania, jak i poziomu wykonawczego, przemawia za grupą kilku rytowników oraz różnymi źródłami inspiracji, czy też wzorcami dla widoków poszczególnych miast.

Jedyną sygnowaną ryciną wśród ilustracji Theatrum jest zamieszczony na sześćdziesiątej drugiej karcie widok Vicenzy [il. 2]. Majuskulny napis: IACOBUS MONTICULUS INVENTOR wpisany w prostokątne pole rollwerkowego kartusza informuje nas, że autorem projektu do ryciny był specjalizujący się w sporządzaniu planów miast rysownik Jacopo Monticolo. Znany jest jego inny, obrócony o dziewięćdziesiąt stopni, widok Vicenzy z 1611 roku opublikowany w oficynie Francesca Valegia (il. 3) ${ }^{24}$. Prezentuje on podobną konwencję obrazowania

${ }^{18}$ Borroni, Bertelli, s. 499-500; Filippi, Bertelli, s. 50.

${ }^{19}$ Borroni, Bertelli, s. 499.

${ }^{20} 104$ plus jedna podwójna prezentująca pochód doży weneckiego.

${ }^{21}$ Doskonały przykład stanowi Diversarum nationum ornatus oraz Additio ad duos superiores libros de habititus publikowany przez Alessandro Fabri w Padwie.

${ }^{22}$ Vite degli imperatori Turchi con loro effigie intagliate in rame, Vicenza 1599. Por. Filippi, Bertelli, s. 50.

${ }^{23}$ Jak wyżej.

${ }^{24}$ R.J. Chandler, The Venetian Arcadia. Andrea Palladio and the reinvention of the antique (2003), w: http://rubens.anu.edu.au/raider4/chandler/chap1.htm (dostęp: 20.07.2007). 
miasta. Zestawiając te ryciny z innymi ilustracjami Theatrum można rozciągnąć autorstwo Monticola na projekty do widoków Udine i Calatii.

Niewiele również powiedzieć można o samych wykonawcach rycin. Zróżnicowanie poziomu opracowania wskazuje na udział w przygotowaniu ilustracji przynajmniej czterech sztycharzy. Należy przypuszczać, że jednym z nich był Pietro Bertelli. Autorstwo części rycin przypisać można też jego synowi Francesco. Na jego udział w omawianym przedsięwzięciu wydawniczym wskazuje sygnowany podpisem fran ${ }^{c o}$ bertelli form (mavit) $i$ datowany na 1599 rok widok Rzymu ze zbiorów biblioteki Fundacji Pol Getty, niemal identyczny z ryciną zamieszczoną w Theatrum (il. 4, 5) ${ }^{25}$. Jest to jedna z wcześniejszych sygnowanych grafik Francesco Bertellego, który w 1599 roku pracował jeszcze w warsztacie swego ojca ${ }^{26}$. Zbieżna data wykonania, identyczne ujęcie oraz opracowanie detalu w obu odbitkach, ponad wszelką wątpliwość wskazują na jednego wykonawcę. Niemal jednakowe są także rozmiary rycin. Milimetrową różnicę w ich długości potraktować można jako błąd pomiarowy lub wynik pomarszczenia się papieru. Obie odbitki pochodziły najprawdopodobniej z jednej, retuszowanej, czy też uzupełnionej o podpis matrycy. Ostatnio na jednej z antykwarycznych aukcji pojawiła się kolejna sygnowana przez Francesco rycina $\mathrm{z}$ repertuaru Theatrum, błędnie przypisywana Ferrando Bertellemu i datowana na lata 70. XVI wieku. U dołu graficznego przedstawienia Valletty na Malcie widnieje podpis fra. ${ }^{c o}$ bertelli for. In Padova, bez wątpienia autorstwa młodszego, mniej znanego przedstawiciela rodu. Każe to przesunąć datowanie ryciny co najmniej o ćwierć wieku.

Niemożliwe było niestety ustalenie pozostałych wykonawców rycin. Brak jakichkolwiek przesłanek stylistycznych, czy archiwalnych pozostawia je pracami anonimowymi.

\section{Typologia ujęć i pierwowzory ikonograficzne miast}

Aby w pełni określić charakter publikacji Bertellego, specyfikę zawartego w niej materiału ilustracyjnego, czy wreszcie ewentualnego wpływu adresata dedykacji na zawartość przygotowywanej książki, niezbędne będzie dokonanie analizy stylistycznej i struktury kompozycyjnej zamieszczonych w niej rycin. Wobec skąpych informacji na temat rysowników i sztycharzy pracujących przy tym przedsięwzięciu, kluczowe mogą okazać się poszukiwania pierwowzorów i bezpośrednich zależności między ilustracjami zdobiącymi Theatrum i grafikami zamieszczonymi w podobnych publikacjach powstałych w przeciągu XVI wieku.

Według zawartych w tekście dedykacyjnym informacji Theatrum miało być swoistą bibliofilską pamiątka, która zawierałaby w sobie „obrazy” miast już widzianych lub tych, które adresat dedykacji pragnąłby ujrzeć [aneks]. Ofiarowaną biskupowi Hieronimowi Rozrażewskiemu publikację zaliczyć można do popularnych w czasach nowożytnych wydawnictw albumowo-przewodnikowych, w których okraszone sugestywnymi ilustracjami opisy zawierają najważniejsze

${ }^{25}$ The Getty Library, sygn. P 850002; F. Bertelli, Small plan of Modern Roma, Venice 1599. Wymiary $120 \times 175 \mathrm{~mm}$.

${ }^{26}$ Borroni, Bertelli, s. 500. 
informacje z zakresu historii, geografii i kultury danego miejsca ${ }^{27}$. Szczególny nacisk kładziono w nich zazwyczaj na historię miast, mniej skupiając się na ich atrakcjach turystycznych. W sferze tekstowej publikacja Bertellego ma ewidentnie wtórny charakter i powiela charakterystyczny schemat dzieł Brauna i Hogenberga. Zgodnie z nim, po wprowadzeniu objaśniającym porządek ustrojowy i zależności administracyjne danego grodu, następowało omówienie historii miasta od jego założenia po czasy współczesne. W ten wywód wplecione zostały informacje o słynnych jego mieszkańcach oraz ważniejszych budowlach. Doskonałym przykładem takiego porządku jest skopiowany z Civitates opis Urbino, w którym autor wiele uwagi poświęcił najznamienitszemu artyście pochodzącemu $\mathrm{z}$ tego miasta - Rafaelowi ${ }^{28}$. Powołując się na Giorgio Vasariego opisał on jego kontakty z Michałem Aniołem, udział w pracach przy budowie Bazyliki świętego Piotra w Rzymie oraz dekoracjach pałacu watykańskiego ${ }^{29}$. W przypadku dzieła Brauna i Hogenberga tekst zazwyczaj nie ma większego wpływu na rytowany obraz miasta (jak w Urbino), ponieważ spora ilość wykorzystanych w Civitates wedut odwzorowano z wcześniejszych prac publikowanych zarówno jako autonomiczne grafiki, jak i ilustracje syntetycznych dzieł Hartmana Schedla czy Sebastiana Münstera ${ }^{30}$. W przypadku interesujących nas wyobrażeń miast włoskich jest jednak kilka przykładów, w których zależności między tekstem a ilustracją są widoczne. Zaliczyć do nich możemy przede wszystkim opisy i weduty powstałe podczas wspólnej podróży po Italii geografa Abrahama Orteliusa z wybitnym rysownikiem i sztycharzem Jorisem Hoefnaglem ${ }^{31}$. W efekcie ich współpracy powstały rozdziały poświęcone takim miastom jak: Terracina, Tivoli, Velletri, Gaeta (Mola), Fondi czy Nocerra. Wszystkie wymienione wyżej miejscowości przedstawione zostały w podobny sposób w Theatrum.

Przejęty przez Pietra Bertellego model opisu wypracowany w Civitates Orbis Terrarum Brauna i Hogenberga wskazuje nam najbardziej prawdopodobne źródło inspiracji dla grafik zamieszczonych w Theatrum. Teza ta z nielicznymi wyjątkami potwierdza się przy porównaniu rycin z obu publikacji, uważniejsza analiza materiału ilustracyjnego ujawnia jednak jego niejednolity charakter oraz zróżnicowany stopnień zależności od domniemanego pierwowzoru. Zamieszczone w dziele

${ }^{27}$ O popularności tego typu publikacji we Włoszech świadczy fakt, że w samej Wenecji w 2. połowie XVI wieku ukazało się przynajmniej dziesięć pozycji o podobnym charakterze. Wśród nich dużą popularność zyskało wydane w 1590 roku L'isole piu famose del mondo Tomasso Porcacchiego czy przywołane już wcześniej Civitatum aliquod insigniorum et locorum magis munitorum exacta delineatio Donato Bertellego. W przypadku tego ostatniego za konotacjami rodzinnymi idzie również podobne opracowanie miedziorytnicze poszczególnych kompozycji.

${ }^{28}$ Por. Bertelli, Theatrum, p. 97 r.

${ }^{29}$ Jak wyżej; Por też: G. Vasari, Żywoty najsławniejszych malarzy, rzeźbiarzy i architektów, oprac. i thum. K. Estreicher, t. 4 ,Warszawa-Kraków 1985. s. 124-162.

${ }^{30}$ F. Bachmann, Die alten Städtebilder. Ein Verzeichnis der graphischen Ortsansichten von Schedel bis Merian, Leipzig 1936, s. 3-6.

${ }^{31}$ Podróż tę odbyli w latach 1577-1578. Podczas niej Ortelius zbierał informacje do opisów natomiast Hoefnagel sporządzał rysunkowe wizerunki odwiedzanych miast. Por. A.E. Popham, George Hoefnagel and the Civitates Orbis Terrarum, „Maso Finiguera”, 1(1936) s. 183-201. 
Bertellego ilustracje nie tworzą pod względem poziomu wykonania tak spójnego zespołu jak te z Civitates, czego nie można tłumaczyć jedynie różnymi wykonawcami poszczególnych rycin. W przypadku niektórych ilustracji daleko posunięte uproszczenia oraz widoczne modyfikacje panoramicznego detalu i postaciowych scen wskazują ponad wszelką wątpliwość na pośrednią znajomość publikowanych przez Brauna i Hogenberga widoków. Gdy dodamy do tego wspomniane wyżej różne pochodzenie wzorców wedut z Civitates, jawi się nam niezwykle zróżnicowany materiał wymagający zarówno typologicznego uporządkowania jak i pogłębionej ikonograficznej oraz stylistycznej. Zasadniczym celem będzie tu wyznaczenie ikonograficznych źródeł i najbliższych wzorców dla jak najszerszej liczby rycin. Rozpoznanie ikonograficznych pierwowzorów musi poprzedzić dokonanie odpowiedniej klasyfikacji typów obrazowania miast. Pewne utrudnienie $\mathrm{w}$ jej przeprowadzeniu stanowią daleko idące uproszczenia, które w kilku przypadkach skutecznie zatarly pierwotny charakter kopiowanej kompozycji.

Już Maria Paola Marabotto próbowała podzielić typologicznie zdobiące Theatrum ryciny, swą uwagę skupiła jednak jedynie na dwóch najbardziej efektownych odmianach ujęć z lotu ptaka - weduty aksonometrycznej i alla militare, zwanej też błędnie kawaleryjską ${ }^{32}$. Wobec różnorodności zgromadzonego w książce materiału ilustracyjnego, zawierającego zarówno przedstawienia ewidentnie archaizujące, jak i rozwiązania na owe czasy nowatorskie, klasyfikacja włoskiej badaczki wymaga gruntownej weryfikacji i rozszerzenia.

Zawarty w dziele Bertellego materiał podzielić można nie na dwa, lecz przynajmniej na sześć zasadniczych zbiorów typologicznych. Najbardziej prymitywną, archaizującą formę reprezentują widoki Urbino, Pavii oraz Udine (il. 6). Ilustracje te w stylistyce swej oparte zostały na późnośredniowiecznych wzorcach obrazowania. Do popularyzacji tej konwencji przyczyniła się wydana przez niemieckiego lekarza i humanistę Hartmana Schedla Kronika Swiata ${ }^{33}$. Cechą charakterystyczną dla tego typu przedstawień jest hierarchiczno-symboliczny, a więc odbiegający od rzeczywistości, sposób portretowania miast ${ }^{34}$ Wizerunki najważniejszych budowli często mają charakter umowny, niemal ikoniczny. Dla większej czytelności przeskalowano je względem reszty zabudowań i rozmieszczono bez większej dbałości o poprawność rozplanowania topograficznego w „strategicznych" dla kompozycji miejscach. W myśl średniowiecznej zasady jasności, ich profilowe sylwetki wzbogacone zostały o widoki ścian bocznych. Pozostałe budynki zakomponowano zazwyczaj według jednego schematu i rozlokowano w układach „warstwicowych”, sugerujących perspektywę z lotu ptaka. Takie ze-

${ }^{32}$ Marabotto, In viaggio per conoscere, rappresentare e conserware ritratti.

${ }^{33}$ H. Schedel, Liber Cronicarum, Nürnberg 1493. Część rysunków do książki wykonał Conrad Celtis.

${ }^{34}$ Typ hierarchiczny w graficznych widokach miast został omówiony przeze mnie na toruńskiej sesji naukowej poświęconej pejzażowi w sztuce nowożytnej. Por. S. Dudzik, The Images of Towns and Cities in the Book Illustrations of the Second Half of $16^{\text {th }}$ Century. Ways of Functioning and Types of Presenting, w: Pejzaż - narodziny gatunku 1400-1600, Materiaty sesji naukowej 23-24 X 2003, red. S. Dudzik, T.J. Żuchowski, Toruń 2004, s. 324-325. 
stawienie spowodowało charakterystyczne odkształcenia przestrzeni i wyraźne błędy skrótów perspektywicznych.

Dwie kolejne grupy typologiczne określić można wspólnym mianem wedut pejzażowych. Obrazy miast zostały w nich wpisane $\mathrm{z}$ dużą pieczołowitością w otaczający krajobraz. Mamy tu do czynienia ze swoistą równowagą w odwzorowaniu przestrzeni zabudowanej i otaczającej ją natury. W kompozycjach tych ważne jest odpowiednie oddanie specyfiki ukształtowania terenu. Przedstawione zazwyczaj na drugim planie miasto przestaje dominować i staje się jednym z elementów wizualnej narracji. W przypadku materiału ilustracyjnego zdobiącego Theatrum takie cechy wykazują przede wszystkim prace wzorowane na rysunkach Hoefnagla. Zależność ta wyjaśnia w dużej mierze specyficzną strategię obrazowania i jej powiązania z konstytuowaniem się poprzez grafikę nowożytnego pejzażu jako autonomicznego gatunku w sztuce. Dobrym odniesieniem może tu być twórczości Campagnoli, artystów z kręgu szkoły Naddunajskiej czy Antonio Tempesty 35 .

W obrębie tego zbioru możemy wyróżnić dwie autonomiczne strategie prezentacji miasta. Pierwsza $\mathrm{z}$ nich zasadza się na rozciągniętym horyzontalnie ujęciu panoramicznym, w którym sylwetka grodu przedstawiona jest na wprost, a większość budowli „nakłada się” na siebie i pozostaje częściowo ukryta za kurtyną obwarowań. Do takiego typu zaliczyć należy widoki Fondi i Treviso (il. 7). Wkomponowana perspektywicznie $\mathrm{w}$ górzysty pejzaż zabudowa bliższa jest rzeczywistości, niż wizerunki z pierwszej grupy. Podobnie jednak jak tam, zastosowano tu zasadę kompensacji i średniowieczny sposób ujęcia nawarstwiających się bezładnie budynków, natomiast najbardziej znaczące konstrukcje znacznie przeskalowano w stosunku do pozostałych. W ilustracjach tych nowożytną w swym charakterze panoramę ,zbudowano" za pomocą archaicznego, średniowiecznego języka form. Liczne uproszczenia zacierają bezpośredni związek z krajobrazowymi przedstawieniami Hoefnagla oraz wzorowanymi na nich rycinami z Civitates. Naznaczony uproszczeniami schematyzm ujęcia paradoksalnie uwypukla genetyczny związek kompozycji Bertellego z doskonałymi panoramami zdobiącymi planimetryczne dzieła Hannsa Lautensacka Augustina Hirschvogla ${ }^{36}$. Warto nadmienić, że zastosowany przez tych artystów panoramiczny model obrazowania Wiednia i Norymbergi z powodzeniem wykorzystany został przez Sebastiana

${ }^{35}$ Por. E. Saccomani, Il paesaggio nel disegno veneziano delia prima meta del Cinquecento: i disegni da collezione, w: Pejzaż-narodziny gatunku 1400-1600, Materiaty sesji naukowej 23-24 X 2003, red. S. Dudzik, T.J. Żuchowski, Toruń 2004, s. 201-216; M. Bóbr, Mistrzowie grafiki europejskiej. Od XV do XVIII wieku, Warszawa 2000, s. 75; M. Bury, Antonio Tempesta as Printmaker: Invention, Drawing and Technique, w: Draving 1400-1600, Invention and Innovation, red. S. Curie, Aldershot 1998, s. 189-205.

${ }^{36}$ Efektem prowadzonych przez Hirschvogla w latach 1546-1547 pomiarów Wiednia było wykonanie dokładnego planu miasta. Jego graficzną wersję uzupełniały dodatkowo dwie panoramy miasta widzianego od południa i północy. Stały się one wzorcem dla wielu europejskich wedut. Podobną pracę dla władz Norymbergii wykonał na początku lat 50. XVI wieku Lautensack. Por. K. Pilz, Hirschvogel Augustin, w: Neue Deutsche Biographie (dalej: NDB), Band 9, Berlin 1972, s. 231; A. Schmitt, Hanns Lautensack, NDB, Band 13, Berlin 1982, s. 729. 
Münstera w Cosmographia Universalis, a za nim w Civitates Orbis Terrarum Brauna i Hogenberga ${ }^{37}$.

Odmienną strategię obrazowania przedstawia widok Gaety (Moli) (il. 8). Ilustracja ta także wzorowana była na wykonanej według Hoefnagla grafice pochodzącej z Civitates Brauna i Hogenberga ${ }^{38}$. Prezentowane na drugim planie miasto przesunięte zostało poza oś główną kompozycji „,dając miejsce” pierwszoplanowej scence rozgrywającej się na usytuowanym w lewym narożniku pagórku. Łącznik między tymi strefami stanowi prowadzący do bram miejskich trakt. Biegnie on od środka dolnej krawędzi ku prawej stronie, by ,łącząc się” z granicą pola obrazowego zmienić kierunek ku otwartemu wjazdowi do miasta. W pierwowzorze ten często stosowany zabieg pogłębić miał iluzję perspektywicznej głębi, tutaj jednak sztycharz nie ustrzegł się daleko idących uproszczeń i błędów perspektywicznych, które zacierają znacząco pierwotną strategię obrazowania.

Widoki sklasyfikowane $w$ tych trzech grupach stanowią jedną trzecią materiału ilustracyjnego Theatrum. Charakterystyczny styl formowania budowli, jak i opracowanie otaczającego grody krajobrazu skłaniają do wniosku, iż ilustracje obu grup rytowane były przez jednego sztycharza. Artysta posługiwał się tutaj daleko idącymi uproszczeniami i kompensacją rzeczywistego widoku, co wraz z przeskalowaniem niektórych budowli dało w efekcie obraz daleki od rzeczywistości. Wizerunki te można określić mianem portretów na poły fantastycznych. Schematyzacja w budowaniu brył poszczególnych budynków posunięta została tu tak daleko, że większość z nich rozpoznać można jedynie dzięki zamieszczonym napisom. Wykonane w języku włoskim objaśnienia oprócz budowli sakralnych najczęściej opisują ważniejsze bramy wjazdowe oraz mosty.

Kolejną, czwartą grupę ilustracji reprezentują widoki wykonanych, jak określiła Marabotto, w aksonometri alla militare ${ }^{39}$. Imaginacyjne ujęcie z perspektywy lotu ptaka podporządkowane zostało tu w równym stopniu zasadom geometrycznego przetworzenia rzeczywistości, jak i chęci utrzymania pełnej rozpoznawalności najbardziej charakterystycznych dla miasta budowli. W ten sposób całość zyskuje charakter hybrydalny, w którym abrys miasta wraz z jego arteriami i placami ukazany jest w odmiennej pespektywie rzutowej niż architektoniczny detal. W tym miejscu zaznaczyć jednak należy, że włoska badaczka omawiając ilustracje z Theatrum zrównała ze sobą dwa odmienne pod względem odwzorowania rzeczywistości typy widoków alla militare.

Szkieletem konstrukcyjnym dla pierwszego z nich jest planimetryczny abrys miasta, rzutowany na płaszczyznę niemal bez żadnych odkształceń. Przykładem tego modelu jest przywoływany przez Marabotto widok Neapolu (il. 9). Zestawiając tę rycinę z wydanym w 1800 roku planem autorstwa Johna Stockdale widać wyraźnie, że abrys miasta i prowadzenie głównych arterii ulega jedynie niewielkim odkształceniom, które wynikają najprawdopodobniej z konieczności dosto-

${ }^{37}$ J. Elliot, The city in Maps urban mapping to 1900, London 1987, s. 28-29.

${ }^{38} \mathrm{~S}$. Dudzik, The Images of Towns and Cities in the Book Illustrations of the Second Half of $16^{\text {th }}$ Century, s. 332 .

${ }^{39}$ Marabotto, In viaggio per conoscere, rappresentare e conserware, s. 2, 4. 
sowania odwzorowywanego miasta do standardowego dla Theatrum kadru ${ }^{40}$. $\mathrm{Na}$ ten prostopadły rzut autor naniósł widziane z góry, z perspektywy ukośnej, kwartały budynków oraz obwarowania. Całość kompozycji dopełnia górzysta linia horyzontu ukazana już na wprost widza. Tak wielokrotnie łamana perspektywa obserwacji była często stosowana w nowożytnych mapach, których ambicją było nie tylko oddanie topografii regionu, ale także rozpoznawalne oddanie jego najważniejszych ośrodków miejskich. Taki „kartograficzny” typ obrazowania miast spopularyzowały po połowie XVI wieku oficyny zaliczane do tzw. „szkoły Lafrerego" ${ }^{41}$. Do tego typu widoków należy zliczyć także ilustrację przedstawiającą Padwę (il. 10). Tutaj autor zrezygnował jednak z linii horyzontu, wyraźniej „spłaszczył” pionową oś kompozycji.

W podobnej konwencji przedstawiono również Parmę, jednak w tym przypadku jakość ryciny znacznie odbiega od wyżej wymienionych. (il. 11). Ilustracja ta sprawia wrażenie pośpiesznie wykonanego szkicu, w którym schematycznie naniesiono fortyfikacje oraz poszczególne budowle. Zabudowę kwartałów przedstawiono sztywno i z dużą nieporadnością w odtworzeniu skrótów perspektywicznych, co świadczy o ogromnych brakach w warsztacie rytownika. Mimo tych mankamentów, rycina ta przedstawia dużą wartość historyczną, mówi nam też wiele o przebiegu prac nad przygotowaniem publikacji. Pośpiech w jakim ją wykonano, świadczyć może o dokonanych w ostatniej chwili uzupełnieniach lub krótkim terminie przygotowania całej publikacji. Plan miasta tylko w ogólnych założeniach przypomina rzeczywistość. Poza różną ilością i proporcjami bastionów zupełnie inny jest też kształt miasta wewnątrz fortyfikacji. Okrągły wraz z promienistymi ulicami i nanizanymi nań placami przypomina bardziej ideowy plan Sforzindy Filareta, czy miasto idealne Girolama Maggi niż plan miasta Palma Nuova ${ }^{42}$. Warto wspomnieć, że sztych ten jest jednym z wcześniejszych publikowanych widoków powstającego wówczas miasta $\mathrm{w}$ wydawnictwach książkowych i jest może nieco fantastyczną, ale zarazem w pełni autorską jego wizją .

Bardziej zaawansowaną odmianą perspektywy militarnej (kawaleryjskiej) jest rozwiązanie, w którym zarówno abrys miast, jak i jego zabudowa poddane są aksonometrycznym przekształceniom. Zaznaczyć należy jednak wyraźnie, że każdy $\mathrm{z}$ tych elementów ukazany jest $\mathrm{w}$ odmiennym geometrycznym porządku ${ }^{43}$. Skośna perspektywa rzutowania abrysu grodu w założeniach swych miała podwójne zadanie: po pierwsze urealnić portret miasta, a po drugie uczytelnić istotne elementy jego zabudowy przy stosunkowo niewielkich odkształceniach porządku miasta

${ }^{40}$ Por. http://historic-cities.huji.ac.il/italy/napoli/maps/stockdale_1800_napoli.html (dostęp: 20.06.2016).

${ }^{41}$ S. Dudzik, The Images of Towns and Cities in the Book Illustrations of the Second Half of $16^{\text {th }}$ Century. s. 334.

${ }^{42}$ Filartete, Trattato di archtettura; G. Maggi, J. Castriotto, Delle fortificatione della Città (...) libri tre, Venetia 1564; H.W. Kruft, Storia delle teorie architettoniche. D Vitruvio al Settecento, Roma 1999, s. 52-53, 138-139, il. 12, 65.

${ }^{43} \mathrm{O}$ specyfice tzw. perspektywy kawaleryjskiej pisał szeroko Maciej Pawlicki. Por. M. Pawlicki, Związi geometryczne XVII-wiecznych widoków miast z ich rzeczywistym rozplanowaniem, „Teka Komisji Urbanistyki i Architektury”, 7 (1973) s. 161-173. 
(arterii miejskich, placów, narysu obwarowań). Przykładem tego typu strategii przedstawienia w Theatrum jest widok Lukki (i1. 12).

Ostatnią grupę tworzą ryciny; podobnie jak w poprzednich miasto zobrazowane zostało z perspektywy lotu ptaka (aksonometryczne ujęcie). Punkt obserwacji umieszczony został tu wysoko nad ziemią pozwalając autorowi zarówno na odtworzenie narysu miasta, jak i sportretowanie ważniejszych jego budowli. Taki typ reprezentują w dziele Bertellego między innymi widoki Mantui, Cremy, Wenecji i Messyny (il. 13). Rzeczywisty obraz poddany został w tych ilustracjach kilku geometrycznym przekształceniom. O ile kształt miasta oddany został według zasad skrótu perspektywicznego, to biegi głównych ulic prowadzonych wzdłuż osi pionowej są do siebie równoległe. Niedoścignionym wzorem dla tego typu przedstawienia był widok Wenecji autorstwa Jacopo Barbari ${ }^{44}$. Po raz pierwszy większa ilość wizerunków w tym typie pojawiła się w dziele Georga Brauna i Franza Hoghenberga ${ }^{45}$.

Do żadnej z wyżej wymienionych grup nie dało się przypisać widoku Tarentu, Puteoli i Starożytnego Rzymu. Odmienne kadrowanie oraz archaiczna nieco konwencja przedstawienia wskazują, że typologicznych wzorców dla tych rycin należy szukać poza dziełem Brauna i Hogenberga. Pewne cechy stylistyczne ilustracji przedstawiającej Tarent zbliżają ją do geograficznych widoków autorstwa starszych przedstawicieli rodu Bertellich - Ferrando i Donato, bądź innych weneckich wydawców specjalizujących się w publikacjach o charakterze geograficzno-przewodnikowym.

Analiza wykorzystanych w publikacji Bertellego sposobów obrazowania miast wykazała zależność dużej części widoków od najpopularniejszych wówczas wydawnictw: Cosmographii i Civitates. Należy jednak zaznaczyć, że znajomość ilustracji z dzieła Münstera była w tym przypadku z pewnością pośrednia, poprzez publikację Brauna i Hogenberga. Doskonałym przykładem takiej zależności jest widok Cagliari, w książce Bertellego stosunkowo bliski ilustracji z $\mathrm{Ci}$ vitates (il. 14, 15, 16). Autorem pierwowzoru do tych rycin był sardyński teolog, historyk i adwokat Sigismondo Arquer ${ }^{46}$. Według jego rysunku powstała ilustracja w Cosmographi, ta natomiast dopiero posłużyła jako wzór do sporządzenia ryciny w dziele Brauna i Hogenberga. Takie zapośredniczenie ikonograficznych rozwią-

${ }^{44} \mathrm{~J}$. Schultz, Jacopo de' Barbari's view of Venice: map making, city views and moralized geography before the year 1500, „Art Bulletin”, 9 (1978) s. 425-474.

${ }^{45}$ Duża część z ponad pięciuset wizerunków oddana była w typie panoramicznym lub typie perspektywy kawaleryjskiej. Braun Georg, Hogenberg Franz, Civitates orbis terrarum, t. 1-6, Köln $1572-$ 1618. Por. W. Bruhn, Alte deutsche Städtebilder: 24 fabrige Blätter nach Georg Braun und Franz Hogenberg, Leipzig 1938, s. 5.

${ }^{46} \mathrm{~W}$ trakcie przygotowań do pierwszej łacińskiej edycji Cosmographii Sebastian Münster zaproponował Arquerowi współpracę. Jej efektem było poświęcone historii i geografii Sardynii Sardinae brevis historia et descriptio (Cosmographia..., s. 242-250) wzbogacone opracowana przez autora mapą wyspy oraz wedutą Cagliari. Por. A. Stella, Arquer Sigismondo, w: Dizionario Biografico degli Italiani, vol. 4, Roma. 1962, s. 302-304; a także M.T. Laneri, La Sardiniae brevis historia et descriptio, w: S. Arquer, Sardiniae brevis historia et descriptio, pod red. M. Laneri, Cagliari 2008, s. XCVII-CLXVII. 
zań poprzez Civitates rozciągnąć można też na kilku innych autorów. Jednym z najczęściej powielanych był Antonio Lafrery, a raczej rytownicy pracujący dla jego oficyny. Doskonałym przykładem takiej ścieżki zależności mogą tu być widoki Messyny, Mediolanu, Ankony, Genui czy Neapolu ${ }^{47}$. Innym znanym autorem, którego kompozycje przejęte zostały za pośrednictwem Civitates, był współpracujący ze wspomnianą wyżej oficyną Lafrerego Flamand Nicolas van Aelst, autor wydanych w Rzymie widoków Galliopoli (1591) oraz Katanii $(1592)^{48}$.

Mimo wielu podobieństw łączących ilustracje zamieszczone w książce Bertellego z analogicznymi kompozycjami publikowanymi przez Brauna i Hogenberga, bezpośrednia zależność dużej części z nich jest raczej wątpliwa. Przemawiają za tym daleko idące uproszczenia $\mathrm{w}$ warstwie kompozycyjnej oraz opracowaniu detali, liczne perspektywiczne nieporadności, a wreszcie wyraźne zacieranie pierwotnej struktury odwzorowania przestrzennego. Wobec tych wszystkich ,anomalii” należy szukać ogniwa łączącego obie publikacje wśród wydawnictw z widokami miast, które ukazały się między ich edycjami, czyli w drugiej połowie lat 90. XVI wieku.

Wśród kilku mieszczących się $\mathrm{w}$ tym kryterium pozycji szczególną uwagę zwraca wydane w Wenecji Raccolta autorstwa Francesco Valegio ${ }^{49}$. W oficynie tego wydawcy i rytownika Monticolo opublikował przywoływany już widok Vicenzy. Znane z kilku wydań dziełko zawiera imponujący zestaw ponad dwustu widoków miast całej Europy, w tym ponad pięćdziesiąt włoskich. Analiza porównawcza bogatego materiału ilustracyjnego obu publikacji ujawnia duże podobieństwo aż czterdziestu dwóch kompozycji, czyli trzech czwartych ilustracji zdobiących Theatrum. Niemal wszystkie z nich wykazują dużą zależność od Civitates. Pierwszą wskazówką przemawiająca za istnieniem bezpośredniego związku między powstaniem publikacji Vallegia i Bertellego jest podobny i, co ważne, ujednolicony format ilustracji, czego nie da się powiedzieć o wedutach zamieszczonych w Civitates. Dostosowanie różnie formatowanych kompozycji do jednego rozmiaru wymusiło w niektórych wypadkach na obu autorach dokonanie daleko idących korekt i przekształceń. W obu publikacjach mają one bardzo podobny charakter, ale dopiero bezpośrednia konfrontacja przedstawień tych samych miast z wszystkich trzech publikacji pozwala ustalić kierunek i stopień zależności. Gdy zestawimy pochodzące z Civitates, Raccolta i Theatrum widoki Terraciny, Moli czy Loreto, w każdym niemalże detalu uwidacznia się wyraźny ciąg zależności prowadzący od dzieła Brauna i Hogenberga po omawianą książkę Bertellego (il. $17,18,19)$. Ryciny Vallegia ewidentnie stanowią tu pośrednie ogniwo przekształceń. Postępujące zmiany widoczne są już na poziomie strategii przestrzennego obrazowania i relacji miedzy portretem grodu i otaczającym go pejzażem. Pochodząca z Civitates ilustracja przedstawiająca Terracinę przybrała kształt leżącego prostokąta o stosunkowo masywnych proporcjach $(33 \times 42.5 \mathrm{~cm})$. Samo miasto

${ }^{47}$ Por. S. Dudzik, The Images of Towns and Cities in the Book Illustrations of the Second Half of $16^{\text {th }}$ Century, s. 325; por. też P. Militello, Ritratti di città in Sicilia e a Malta (XVI-XVII secolo), Palermo 2008, s. 58, 74.

${ }^{48}$ P. Militello, Ritratti di città in Sicilia e a Malta, s. 59, 75.

${ }^{49} \mathrm{~F}$. Vallegio (Valesio), Raccolta di li più illustri et famose città di tutto il mondo, Venetiis bd. 
ukazane zostało na drugim planie z dość odległej perspektywy (il. 17). W kompozycji dominuje górzysty krajobraz. Przestrzenną głębię Autor osiągnął poprzez „rozciągnięcie” pierwszego planu i umieszczenie sylwetki grodu powyżej osi poziomej kadru. W relacjach płaszczyznowych zajmuje ona stosunkowo niewielki obszar w lewej górnej ćwierci obrazowej płaszczyzny. W porównaniu z tą ilustracją proporcje pracy autorstwa Vallegia mają bardziej panoramiczny charakter, czego nie można jednak powiedzieć o samej sylwecie miasta (il. 18). Efektem „wysmuklenia” kadru było znaczące „skrócenie” dystansu między widzem i miastem. To przestrzenne spłaszczenie kompozycji wzmocnione zostało dodatkowo przeskalowaniem zabudowań w stosunku do otaczającego je górzystego pejzażu. Dzięki tym zabiegom obraz miasta zajmuje wyraźnie większą część kadru niż w pierwowzorze. Patrząc na wszystkie te zabiegi można wnioskować, że intencją autora było nie tylko dopasowanie struktury kompozycyjnej do znormalizowanych w całej książce rozmiarów ilustracji, ale także wyraźne hierarchiczne osłabienie dominacji naturalnego pejzażu na rzecz miasta. Tendencja ta została jeszcze bardziej pogłębiona w ilustracji zamieszczonej u Bertellego (il. 19). Co istotne, za zwiększeniem rozmiarów poszczególnych budowli, zarówno Raccolta, jak i w Theatrum nie idzie wcale większa pieczołowitość w oddawaniu ich detali. Jest wręcz odwrotnie - mamy do czynienia z postępującym upraszczaniem i barbaryzacją poszczególnych elementów. Widać to wyraźnie w porównaniu organizacji zabudowy i detalach tkanki miejskiej Loreto oraz Gaety (Moli) (il. 8, 20, 21). Doskonałym przykładem tej tendencji jest obraz bramy wjazdowej do drugiego z miast. W Raccolta czytelne są jeszcze umieszczone na niej tarcze herbowe, choć źle zinterpretowany został wąski otwór strzelniczy przedstawiony w Civitates na osi budowli. W dziele Bertellego po tych detalach nie ma już śladu, prostokątną blendę na osi zastępuje okulus. Taki sam kierunek przeobrażeń wykazują również scenki rodzajowe rozgrywające się w pobliżu prowadzących do miasta traktów. Przykładem mogą tu być postacie przedstawione w widoku Terraciny (grupa zbierająca owoce) czy Moli (jeździec i wędkarz). Kolejnym ważnym elementem potwierdzającym bliższą zależność dzieła Bertellego od publikacji Valegia niż Brauna i Hogenberga jest wierne powtórzenie umieszczonych w ramkach inskrypcji. Co istotne, różnią się one od tych, które komentują widoki z Civitates. Prawidłowość barbaryzowania form dostrzec można nawet w samym sposobie ramowania. W pierwowzorze ozdobione jest ono formą okuciowo-rollwerkową o wyraźnym przestrzennym ukształtowaniu. U Vallegia końcówki okuciowej blachy są już tylko lekko wygięte, a w dziele Bertellego ich rysunek jest już całkowicie płaski.

Wszystkie te sygnały sprawiają, że z dużym prawdopodobieństwem to właśnie w Raccolta możemy upatrywać bezpośredniego wzorca dla większości ilustracji Theatrum. Choć powstanie publikacji Valegia datuje się w szerokim przedziale między 1580 a 1626 rokiem, porównanie kilku rycin pozwala niemal bezspornie ustalić zależność Theatrum od Raccolta i przesunąć datowanie tej ostatniej publikacji przed rok 1599.

Pozostaje jeszcze grupa kilkunastu rycin nie dających się powiązać z wydaniem Valegia. Zaliczyć możemy do niej kilka sztychów prezentujących najwyższy poziom wykonawczy - widok Padwy, Messyny i Cagliari. Chociaż Messyna 
posiada swój odpowiednik w dziele Valegia, jednak bliższa wydaje się widokowi zamieszczonemu w Civitates. Wystarczy zwrócić uwagę na prowadzenie głównych arterii miasta, które w Theatrum... niemal wiernie powtarzają przebieg ulic w dziele Brauna i Hogenberga. Takiego uporządkowania brakuje u Valegia. Również potraktowanie detalu w ilustracjach pochodzących z książki Bertellego bliższe jest kolońskiemu wydawnictwu lub, co też prawdopodobne, pierwowzorowi Nicolasa van Aelsta rozpowszechnionemu przez powiązaną z rodziną Bertellich oficyną Lafrerego. Podobnie też może być z wyróżniającymi się na tle innych widokami Wenecji, Malty oraz Tarentum. Według Juergena Schultza pierwowzorem dla wizerunku Wenecji w dziele Bertellego była datowana na rok 1566 rycina autorstwa Paola Forlaniego ${ }^{50}$. Z tej kompozycji korzystał również Donato Bertelli w swojej Le vere imagini, którego ilustracje wykazują dużą zbieżność stylistyczną z przedstawieniami Taranto i Malty ${ }^{51}$. Być może właśnie tutaj należałoby szukać bezpośrednich wzorców.

Z wydaniem Raccolta nie da się powiązać również omówionych już wcześniej wedut Palmy, Vicenzy oraz Udine i Calatii.

\section{Udział polskiego biskupa w przygotowaniu publikacji}

Adresat zamieszczonej w Theatrum dedykacji - biskup Hieronim Rozrażewski - należał z pewnością do intelektualnej elity Rzeczpospolitej. Ten kształcony w Ingolstadt i Rzymie polski hierarcha żywo interesował się literaturą, bezpośrednio wspierał też liczne przedsięwzięcia wydawnicze. Już przez współczesnych postrzegany był jako wielki miłośnik książek. Odbiciem tego był choćby zgromadzony przez niego bogaty, liczący blisko 700 woluminów, księgozbiór biblioteczny ${ }^{52}$ Stosunek biskupa do książek, podobnie jak zawartość jego księgozbioru, były przedmiotem wnikliwych badań wielu naukowców. Począwszy od Stanisława Chodyńskiego i Ignacego Polkowskiego, którzy w latach 80. XIX stulecia jako pierwsi zajęli się analizą dokumentów testamentowych Hieronima Rozrażewskiego, problem biblioteki i książek pojawiał się niemal we wszystkich pracach poświęconych działalności tego dostojnika ${ }^{53}$. Wiele informacji na temat tych zagadnień wniosły publikacje Pawła Czaplewskiego i Ludwika Grzebienia $^{54}$. Doskonałe uzupełnienie zawartych tam informacji znalazło się w monografii bibliotek kartuzów w Berezie Kartuskiej i Gidlach autorstwa Krzysztofa

${ }^{50}$ Schultz, The printed, s. 31.

${ }^{51} \mathrm{D}$. Bertelli, Le vere imagini et descritioni delle più nobilli città dell mondo, Venezia 1569.

${ }^{52}$ Por. Grzebień, Biblioteka biskupa Hieronima Rozrażewskiego, s. 94.

53 S. Chodyński, Testament biskupa Hieronima Rozdrażewskiego biskupa włocławskiego z r. 1599, „Przegląd Katolicki”, 21 (1883) nr 3, s. 509-513; I. Polkowski, Jeszcze o testamencie biskupa Hieronima Rozrażewskiego, „Przegląd Katolicki”, 22 (1884) s. 473-374.

${ }^{54}$ Monograficzna praca Ludwika Grzebienia zawiera krytyczną publikację sporządzonego w maju 1600 roku inwentarza ksiąg przekazanych jezuitom gdańskim. Por.: P. Czaplewski, Hieronim Rozrażewski a książka, „Silva Rerum”, 1/2 (1938) s. 9-15; Grzebień, Biblioteka biskupa Hieronima Rozrażewskiego s. 61-169. 
Nierzwickiego ${ }^{55}$. Pozycje te, w szczególności monografia biskupiej biblioteki, w dużej części wyczerpują problematykę księgozbioru i zainteresowań czytelniczych Rozrażewskiego, pomijają jednak niezwykle ważny problem, jakim jest rekonstrukcja bezpośrednich związków dostojnika z twórcami oraz jego udział powstawaniu konkretnych publikacji. Analiza tej sfery aktywności kulturalnej i intelektualnej biskupa pozwala nam określić w równym stopniu, wiedzę na temat zawartości i sposobu formowania biblioteki oraz miejsce i rolę biskupa w elitach Rzeczypospolitej i Europy u schyłku szesnastego stulecia. Pod tym względem wiele wyjaśnić może przybliżenie okoliczności powstania omawianego dzieła Pietra Bertellego.

Dedykowanie Rozrażewskiemu publikacji zawierającej ozdobione wedutami charakterystyki miast włoskich z pewnością nie było przypadkowe. Biskup żywo interesował się zarówno historią, jak i geografią. O jego zamiłowaniu do tego typu publikacji świadczy odnotowana w inwentarzu zawartość jego biblioteki. Znalazło się w niej kilkanaście pozycji o podobnym charakterze. Wśród nich są choćby trzy pierwsze tomy przywoływanego już wielokrotnie Civitates Orbis Terrarum Georga Brauna i Fransa Hogenberga ${ }^{56}$. Kolejną pozycją zasługującą na uwagę było Mirabilis Urbis Romae jeden z bardziej znanych i wielokrotnie wznawianych przewodników po zabytkach Rzymu ${ }^{57}$. Widokom miast i fortyfikacji z całego świata poświęcone było dzieło Antoina du Pinet Plantz pourtraitz et descriptions de plusiers villes et fortresses tant del'Europe, Asie et Afrique, que des Indes, wydane w Lionie w $1564^{58}$. Do tego nurtu zaliczało się również bliżej nieokreślone Itinerarium Germanice ad varia partes orbis ${ }^{59}$. Bez wątpienia część z tych pozycji, jak choćby Civitates czy Plantz pourtraitz, była wydaniami bibliofilskimi zawierającymi bogaty materiał ilustracyjny. Taki zestaw daje nam już pewne pojęcie o upodobaniach biskupa. $\mathrm{Z}$ pewnością wysoko cenił pięknie ilustrowane książki o charakterze geograficzno-przewodnikowym. Doskonałym pretekstem do zamówienia podobnego dzieła stała się pielgrzymka bpa H. Rozrażewskiego do Rzymu na Wielki Jubileusz 1600 roku.

Swoją podróż do Wiecznego Miasta biskup przygotowywał niezwykle pieczołowicie, czego ślady znajdziemy w sporządzonym przed wyjazdem testamencie ${ }^{60}$. Uważna lektura tego dokumentu ujawnia liczne plany zakupowe biskupa podczas pobytu w Italii. Jako człowiek świetnie zaznajomiony z kulturą dworską, niezwykle dbający o odpowiednią prezentację własnej osoby, mógł też myśleć o spektakularnej inicjatywie, jaką było wydanie przewodnika poświęconego włoskim miastom. Tekst umieszczonej we frontyspisie inskrypcji oraz zawartość dedykacji wskazują na bezpośredni udział biskupa w powstaniu książki. Pozostaje jedynie

${ }^{55}$ K. Nierzwicki, Biblioteki Kartuzji Kaszubskiej oraz jej konwentów filialnych w Berezie Kartuskiej $i$ Gidlach, Pelplin 2001.

${ }^{56}$ Grzebień, Biblioteka biskupa Hieronima Rozrażewskiego, s. 111, 137.

${ }^{57}$ Tamże, s. 132, 163.

${ }^{58}$ Tamże, s. 138.

${ }^{59}$ Tamże, s. 132.

${ }^{60}$ Por. Testamentum olim reverendissimi domini Hieronymi comitis a Rozrażov, episcopi Wladislaviensis, w: Monumenta historica dioeceseos Wladislaviensis, t. 2, Wladislaviae 1882, s. 13-15. 
pytanie, czy jego wkład ograniczył się jedynie do okazjonalnego - finansowego wsparcia wydawnictwa, czy też można go uznać za osobę współodpowiedzialną za treść i dobór materiału ilustracyjnego?

Odpowiedź na to pytanie daje w pewnym stopniu już sam tekst dedykacyjny. Pietro Bertelli wychwalając roztoczony nad republika pisarska mecenat Rozrażewskiego sugeruje poniekąd jego inicjatywę w doborze miast włoskich. Zgodnie ze słowami padewskiego wydawcy książka zawierać miała miejsca już widziane przez biskupa lub te, które chciałby odwiedzić [por. aneks]. Z zapisu tego wynika, że Bertelli znał przeszłość polskiego biskupa i wiedział, że ten był już wcześniej w Italii. Co więcej, można się domyślić, że był świadomy jego wcześniejszej działalności kulturalnej oraz upodobań. Zarówno w publikowanej korespondencji biskupa, jak i w odnalezionych dokumentach archiwalnych, brak jest jednak jakichkolwiek śladów ich wcześniejszej znajomości. Informacje o dostawcach i wydawcach włoskich zaopatrujących bibliotekę Rozrażewskiego są zbyt ogólnikowe i ograniczają się raczej do sygnałów o otrzymaniu przesyłki i ilości książek. Dokładne odtworzenie ich listy utrudnia fakt, że większość książek docierała do Rozrażewskiego za pośrednictwem jego przyjaciół. W latach siedemdziesiątych korzystał na przykład z uprzejmości Gratianiego, który dostarczał mu wydane w Wenecji mapy i książki ${ }^{61}$. W późniejszym okresie książki zdobywał dla niego brat Stanisław oraz zaprzyjaźniony nuncjusz apostolski przy cesarzu - Bonhomini. Nici łączących obie postacie należy więc szukać gdzie indziej.

Brak informacji o wcześniejszych kontaktach biskupa z padewskim wydawcą nie przekreśla możliwości bezpośredniego udziału dostojnika w powstaniu Theatrum, czyni natomiast bardziej prawdopodobną tezę o przygotowaniu publikacji podczas pobytu Hieronima Rozrażewskiego w okolicach Padwy i Wenecji. Powiązanie powstania książki z jego pielgrzymką do Rzymu, wyznacza ramy czasowe pracy nad jej przygotowaniem na okres między majem a październikiem 1599 roku. Z korespondencji biskupa wynika, że odwiedził on dwukrotnie zarówno w Padwę, jak i Wenecję. Pięciomiesięczny okres między pierwszymi i drugimi odwiedzinami Serenissimej to czas wystarczający, aby ukończyć przygotowania do druku. Umieszczona na końcu tekstu dedykacyjnego data 19 października 1599 roku zbieżna jest z momentem wyjazdu Rozrażewskiego z Padwy. Biskup miał więc czas aby zaakceptować przygotowany do druku materiał.

Pozostaje pytanie, dlaczego wybór padł akurat na padewską oficynę Bertellego? Kluczową rolę w nawiązaniu kontaktu między Bertellim i Rozrażewskim mógł odegrać wieloletni zaufany, sekretarz biskupa, kustosz kościoła św. Michała w Krakowie - Tomasz Bucki. W datowanym na 15 października 1597 roku liście Rozrażewskiego do generała zakonu jezuitów Aquaviwy, polecał on adresatowi swego sekretarza, udającego się na studia do Rzymu ${ }^{62}$. Pierwszym etapem kształcenia dla Buckiego nie była jednak rzymska uczelnia lecz uniwersytet w Padwie ${ }^{63}$. Gdy polski hierarcha przybył wiosną 1599 roku do tego miasta, jego

${ }^{61}$ Grzebień, Biblioteka biskupa Hieronima Rozrażewskiego, s. 87.

${ }^{62}$ Czaplewski, Korespondencja, t. 2, Toruń 1939, s. 368.

${ }^{63} \mathrm{~W}$ datowanym na 15 października 1597 roku liście do Akwawiwy Rozrażewski polecał udającego się na studia do Italii Tomasza Buckiego. Akta nacji polskiej w Padwie zawierają natomiast 
były sekretarz dołączył do biskupiego orszaku i nie opuścił swego opiekuna aż do śmierci. To jego ręką spisany został kodycyl testamentowy. W dokumencie tym na marginesie, znajduje też się notatka Buckiego o śmierci dostojnika ${ }^{64}$. Jak dużym cieszył się on zaufaniem Rozrażewskiego świadczy zapis testamentowy, w którym na ukończenie rzymskich studiów swego sekretarza przeznaczył on sto skudów ${ }^{65}$. Wszystko wskazuje na to, że to Tomasz Bucki przygotowywał pobyt biskupa w Padwie i Wenecji. Mógł też skontaktować biskupa z tamtejszym wydawcą Pietrem Bertellim. Obecność dostojnika na miejscu nie wymagała ani korespondencji, ani dodatkowych formalności, co tłumaczyłoby brak dokumentów traktujących o jego zaangażowaniu w omawiane przedsięwzięcie wydawnicze.

Za takim scenariuszem powstania książki przemawia również pośpiech, w jakim ją przygotowywano. Analiza językowa tekstu dedykacyjnego wykazała istnienie wielu błędów w składni i fleksji. Również rozmieszczenie znaków interpunkcyjnych pozostawia tu wiele do życzenia. Niechlujny skład świadczyć może o krótkim terminie przygotowania publikacji. Niedopracowanie takich sztychów jak Palma Nuova także znamionuje pośpiech, którego przyczyną był z najprawdopodobniej narzucony przez biskupa termin poprzedzający otwarcie obchodów Roku Jubileuszowego. Prezentowany w Theatrum wybór widoków miast, pokrywający się $\mathrm{w}$ dużej części z repertuarem znanym Rozrażewskiemu z innych posiadanych przez niego publikacji (w tym Civitates), to kolejny argument przemawiający za jego zaangażowaniem w przygotowanie publikacji.

Wszystkie wymienione wyżej elementy wskazują na to, że udział bpa H. Rozrażewskiego w powstaniu książki nie ograniczył się jedynie do wsparcia finansowego. Publikacja Theatrum jest więc niezwykle cennym świadectwem aspiracji oraz zainteresowań kulturalnych polskiego hierarchy. To niewielkich rozmiarów wydawnictwo mogło stanowić doskonałą pamiątkę, a raczej elegancki upominek z pielgrzymki dla przyjaciół lub osób znaczących. Niestety choroba i przedwczesna śmierć w Rzymie najprawdopodobniej pokrzyżowała owe plany.

\section{Oddziaływanie publikacji}

O sukcesie wydawniczym Pietra Bertellego, jakim była publikacja Theatrum, świadczą przede wszystkim liczne wznowienia i naśladownictwa książki.

Jej pierwsza reedycja ukazała w Vicenzie w 1616 roku pod włoskim tytułem Teatro delle città d'Italia ${ }^{66}$. Wydano ją staraniem oficyny Domenica Amadio. W stosunku do wydania pierwszego, dodano osiem dalszych tablic, podmieniono też kilkanaście kolejnych rycin. Zabieg ten był najprawdopodobniej podyktowany zużyciem oryginalnych matryc. Najczęściej dosyć wiernie naśladowano wówczas kompozycje z Theatrum, jednak w przypadku widoku Parmy starą wersję zastąpiła nowa, bardziej atrakcyjna kompozycja. Ten „nowy” widok błędnie przypisany

informacje o opłacie wniesionej przez Buckiego do kasy uniwersyteckiej na ukończenie studiów w 1599 roku Por. Czaplewski, Korespondencja, t. 2, s. 549 [list nr 1203].

${ }^{64}$ Tenor, s. 36.

${ }^{65}$ Tamże, s. 34.

${ }^{66}$ Por. Dizionario, t. 9, Roma 1967, s. 500. 
został przez Francesco da Mareto i Fracnesco Miani pierwszej edycji Bertelle$\mathrm{go}^{67}$. Drugie wznowienie Theatrum ukazało się w 1629 roku staraniem syna Pietra - Francesco Bertellego. Nosiło tytuł Aggiunta al Teatro delle città. W tej wersji wydawca dokonał kolejnych zmian w materiale ilustracyjnym. Podmienione przez Francesca ilustracje wiernie powtarzają kompozycje $z$ Theatrum, jednak sposób ich opracowania oraz nieznaczne przesunięcia elementów kompozycji wskazują na to że odbite zostały z różnych matryc (il. 19, 22).

O sile oddziaływania i sporej popularności dzieła Bertellego, oprócz kolejnych edycji, świadczą przede wszystkim przedsięwzięcia wydawnicze ewidentnie nim inspirowane. Pierwszy taki przypadek został już wcześniej opisany i dotyczył niezrealizowanego projektu biskupa Angelo Rocca ${ }^{68}$. Porządek autorskiego kwestrionariusza dołączonego do egzemplarza omawianej książki wyraźnie zdradza inspirację zawartością Theatrum. W 1663 roku wydano wzorowane na tej publikacji dzieło znanego kartografa Joana Bleau (1596-1673) - Theatrum civitatum admirandorum Italiae. Opublikowana w Amsterdamie książka wykazuje bliskie pokrewieństwo z omawianą publikacją zarówno w konstrukcji tekstu, jak i materiale ilustracyjnym. Przykładem może być tutaj rycina przedstawiająca Cagliari, której kompozycja bezsprzecznie odwzorowana została z ilustracji Bertellego.

Innym, niezwykle frapującym wątkiem, w którym da się uchwycić oddziaływanie Theatrum na inne geograficzno-przewodnikowe przedsięwzięcia wydawnicze, jest historia kolejnych włoskich wydań dzieła Itineraria d'Italia autorstwa Fraza Schota (Francesco Scotto). Spisany przez antwerpskiego radcę prawnego przewodnik zredagowany został przez jego brata - jezuitę, filologa i miłośnika geografii, z myślą o pielgrzymach wybierających się do Rzymu na Wielki Jubileusz $1600 \mathrm{roku}^{69}$. Pierwsza włoska edycja tego dzieła ukazała się już 1601 roku staraniem dwójki padewskich wydawców: Francesco Bolzetta i Pietro Bertellego $^{70}$. Warto zauważyć, że łacińskie tłumaczenie i wydanie dzieła Schota miało miejsce tuż po opublikowaniu Theatrum i zapewne to właśnie praca nad tym dziełem zwróciła uwagę Bertellego na inne, podobne mu dzieła. Sytuacja jawi się jeszcze ciekawiej, gdy przeanalizujemy materiał ilustracyjny kolejnych siedemnastowiecznych wydań Itinerario d'Italia. W wielu z nich znalazły się ryciny ewidentnie wzorowane na tych pochodzących z Theatrum. Doskonałym przykładem tych zależności mogą być choćby widoki Terraciny zamieszczone w wydaniach z 1669 i 1670 roku (il. 23, 24) ${ }^{71}$.

Oddziaływanie książki Bertellego siega aż początków XVIII wieku. Ponad sto dziesięć lat od pierwszej edycji włoski sztycharz - Raphael Savanarola zwany

${ }^{67}$ Por. F. da Mareto, Parma e Piacenza nei secoli, Parma 1975, s. 40, 50; F. Miani, Parma, i modi di vedere una cittá, Parma 1985, s. 13.

${ }^{68}$ Zobacz przypisy 7-8.

${ }^{69}$ G. Valente, L'itinerario d'Italia di Franz Schott: un prototipo seicentesco della guida per il viaggio in Italia, w: F. Schot, Itinerario overo descriitione de'viaggi principali in Italia, Padova [reprint wydania 1670 roku], Edizioni CISVA 2009, s . III.

${ }^{70}$ Tamże, s. III-IV.

${ }^{71}$ Wydawcą tych edycji był Matteo Cadorini. Por. G. Valente, L'itinerario d'Italia di Franz Schott, s. IV. 
Lasor a Vaera - opublikował widok Padwy, którego kompozycja oraz detal bez wątpienia wzorowane były na rycinie $\mathrm{z}$ Theatrum $^{72}$.

$* * *$

Wydanie dedykowanej bp Hieronimowi Rozrażewskiemu książki Bertellego przypadło na czas wielkiej intensyfikacji kontaktów kulturalnych między Polską i Italią ${ }^{73}$. Wykazane powyżej duże prawdopodobieństwo bezpośredniego zaangażowania bpa H. Rozrażewskiego w powstanie książki oraz wybór zamieszczonych w niej materiałów świadczy o wielopłaszczyznowej naturze tych związków. W jakimś stopniu uwidacznia też sięgającą daleko poza granice Rzeczypospolitej kulturotwórczą rolę polskich elit.

Książka Bertellego, mimo iż nie stoi na najwyższym poziomie edytorskim, a jakość wielu zamieszczonych w niej ilustracji pozostawia sporo do życzenia, jest cennym dokumentem obrazującym jeden $z$ etapów formowania się i popularyzacji powtarzanej przez dziesięciolecia ikonografii różnych miast włoskich. Bez wątpienia dzieło Bertellego odegrało w tym procesie znaczącą rolę.

Słowa kluczowe: biskup Hieronim Rozrażewski; Bertelli Pietro, grafika książkowa XVI w., weduta, widoki miast włoskich, ikonografia miast włoskich, Theatrum urbium Italicarum, Jacopo Monticolo

${ }^{72}$ Rafael Savanarola zw. Lasor a Vaera, Widok Padwy, 1713.

${ }^{73}$ Doskonałą charakterystykę tego okresu przedstawił w swej pracy Ulewicz. Por. T. Ulewicz, Iter Romano-Italicum Polonorum. czyli o zwiąkach umystowo-kulturalnych Polski z Włochami w wiekach średnich i renesansie, Kraków 1999, s. 240-280 


\section{ANEKS 1a}

\section{ILLUSTRISSIMO ET REVERENDISSIMO D. D.}

Hieronymo Comitia Rozrazew Episcopo Vladislaviensi \& Pomeraniae Rege Poloniae Senatori Foel \& S. D. ${ }^{74}$

Si quisquam mortalium ex veterum more, quem aliqua rerum varietas ceperit

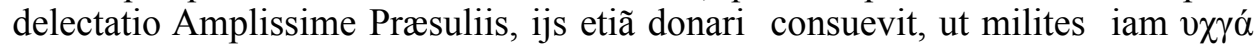

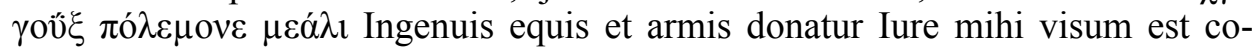
nvenire ut hoc pulcherimarum totius Italia Civitatum à me brevi hoc compendio collectarum quas visendi Semper cupiditate flagrasti simulacrum, tui potissimum nominis auspicijs Illustrime Antistes in manus hominum exiret: primum quòd unus omnium apud nos rei literaria candidissime fave as ergaq; bonarum artium peritos alter Mæcenas existas Porrò quod maximum est cum non exiqo tui decore nemo (et si undiq[] virtutibus refulgeat) sit te dignitas illius quam obtiones, obtiones autem meritis simo, studiosior, cum profecto sis totus ad gloriam totus ad res maximas gerendas natus, Antistes genitus ad utilitatem Christianæ Reipublicæ sis novum ornamentum Sedi Apostolicæ additum, ad propagandam cohonestandam ampliandam Imperij ac familiæ tua Maiestatem datus divinitus. Cum numini, quam homini prior esse videaris. Tandem pluribus alijs causis eram adductus, ut hoc opus, quale quale esset, tui nominis ut dixi, immortalitati consecravetur; siquidem huius modi dignitas, qua nulla hodie sol aspicit, nec latins patentem, nec magis florentem, quidquid opum, quidquid nobilitas, quidquid splendoris con sequitur, id totum certatim ad tuam gloriam, et decus deprompsit adq[] diffundit Itaq[] cum tui splendorem oratione, copiaq[] dicendi (cuius succo parum sum irrigatus) substinere non valeam, verissimè enim cecinit . Vates Lyricus Neq[] enim cuiusuis penicillo numinuum effigies dignè reprasentantur, hoc munusculum te maxime decens eo accipe animo, ut licet perexiguum sit, magnum tamen pietatis, amoris, et observantia in te mea monumentum esse existimes, Vale Mæcenas suaiussime meq[] quòd et potes et tibi datum est . unus omnium maximè fortier defende.

Dat. Patavij xij Kal. Septemb. M.D. IC.

Tua Ilustriss. et Reverendiss.

Dominationi

Servus addictissimus

Petrus Bertellius

\footnotetext{
${ }^{74}$ P. Bertelli, Theatrum urbium Italicarum, Venetiis 1599, k. 2-3.
} 


\section{ANEKS 1b}

\section{NAJDOSTOJNIEJSZEMU I NAJCZCIGODNIEJSZEMU PANU Hieronimowi Hrabiemu na Rozrażewie Biskupowi Wloctawskiemu i Pomorskiemu Senatorowi Królestwa Polskiego, przesyłam serdeczności i pozdrowienia ${ }^{75}$}

Jaśnie oświecony Biskupie, jeśli, wedle zwyczaju przodków, ktoś ze śmiertelnych, któremu sprawiła uradowanie jakaś rozmaitość rzeczy, nawykł nadto oddawać się tym rzeczom, podobnie jak żołnierze na wojnach wspaniałym rumakom i broni, uznałem przeto, że zaprawdę jest rzeczą stosowną, aby to przedstawienie najpiękniejszych miast całej Italii, które zawsze zobaczyć pragnąłeś, a które zebrałem w tym krótkim kompendium, wyszło do rąk ludzkich najlepiej pod auspicjami twego, Najdostojniejszy Biskupie, imienia. Przede wszystkim, ponieważ jako pierwszy ze wszystkich najjaśniej sprzyjasz pośród nas działalności literackiej i okazujesz się drugim Mecenasem wobec wykształconych w zakresie sztuk wyzwolonych. Następnie co jest najważniejsze, ponieważ nikt, nawet jeśli pod każdym względem promieniowałby zaletami, nie jest bardziej od Ciebie, Biskupie, staranny, jeśli chodzi o niemały blask tej godności, którą posiadasz, posiadasz zaś najbardziej zasłużenie, jako że z pewnością cały zrodziłeś się do sławy, cały do największych czynów. Przyszedłeś na świat ku pożytkowi Chrystusowego Państwa jako nowa ozdoba dodana Stolicy Apostolskiej, z łaski Boga przeznaczony do rozszerzania, uwielbiania i udoskonalania majestatu władzy i twojej rodziny. Może wydawać się, że jesteś przynależny raczej Woli Bożej niż człowiekowi. Wreszcie wiele innych przyczyn skłoniło mnie, aby dzieło to, jakiekolwiek by nie było, poświęcić nieśmiertelności imienia twego. Jeśli tylko tego rodzaju wspaniałość, bez której nie sposób dzisiaj dostrzec słońca, nie dorównuje komuś bardziej widocznemu albo bardziej znacznemu, albo też jakiemukolwiek bogactwu, godności bądź chwale, idę o zakład, że całe to dzieło ku twojej chwale i czci [zalety te] wydobywa i rozszerza, aczkolwiek nie jestem w stanie wspierać świetności twojej darem wymowy i jej obfitością, której moc napełniła mnie w zbyt małym stopniu, albowiem najbardziej prawdziwie opiewał poeta liryczny. Nikt zaś nie posiada stylu [pisania], który godnie przedstawia wizerunki bogów. Ten niewielki, zdobiący Ciebie, podarek przyjmij z tą myślą, że choć jest bardzo mały, jednak możesz uznać, że stanowi wielki dowód mego przywiązania, miłości i uszanowania względem ciebie. Pozostawaj w zdrowiu, najłaskawszy Mecenasie i, na ile możesz, na ile jest to tobie dane, jako jeden ze wszystkich [jedyny] długo zachowaj mnie w opiece.

Datowane w Padwie, 19 września 1599 roku.

Twój Najdostojniejszy i Najczcigodniejszy

Panie

Oddany sługa

${ }^{75}$ Tłum. Bartosz Awianowicz. 


\section{BIBLIOGRAFIA}

Bachmann Friedrich, Die alten Städtebilder. Ein Verzeichnis der graphischen Ortsansichten von Schedel bis Merian, Leipzig 1936.

Bertelli Donato, Le vere imagini et descritioni delle più nobilli città dell mondo, Venezia 1569.

Bertelli Ferrando, Civitatum aliquod insigniorum et locorum, Venetiis 1568.

Bertelli Pietro, Vite degli imperatori Turchi con loro effigie intagliate in rame, Vicenza 1599.

Borroni Fabia, Bertelli Pietro, w: Dizionario Biografico degli Italiani, t. 9, Roma 1967, s. 499-500.

Borroni Salvadori Fabia, Carte, piante e stampe storiche delle raccolte lafreriane della Biblioteca Nazionale di Firenze, Rome 1980.

Bóbr Maciej, Mistrzowie grafiki europejskiej. Od XV do XVIII wieku, Warszawa 2000.

Braun Georg, Hogenberg Franz, Civitates orbis terrarum, t. 1-6, Köln 1572- 1618.

Bruhn Wolfgang, Alte deutsche Städtebilder: 24 fabrige Blätter nach Georg Braun und Franz Hogenberg, Leipzig 1938.

Bury Michael, Antonio Tempesta as Printmaker: Invention, Drawing and Technique, w: Drawing 1400-1600, Invention and Innovation, red. S. Curie, Aldershot 1998, s. 189205.

Chandler Rebecca Jade, The Venetian Arcadia. Andrea Palladio and the reinvention of the antique, 2003, w: http://rubens.anu.edu.au/raider4/chandler/chap1.htm (dostęp: 20.07.2007).

Chodyński Stanisław, Testament biskupa Hieronima Rozdrażewskiego biskupa włocławskiego, z r. 1599, „Przegląd Katolicki”, 21(1883) nr 3, s. 509-513.

Czaplewski Paweł, Hieronim Rozrażewski a książka, „Silva Rerum”,1/2 (1938) s. 9-15.

Czaplewski Paweł, Korespondencja biskupa Hieronima Rozrażewskiego, t. 2, Toruń 1939.

da Mareto Felice, Parma e Piacenza nei secoli, Parma 1975.

Dudzik Sebastian, The Images of Towns and Cities in the Book Illustrations of the Second Half of $16^{\text {th }}$ Century. Ways of Functioning and Types of Presenting, w: Pejzaz - narodziny gatunku 1400-1600, Materiały sesji naukowej 23-24 X 2003, red. S. Dudzik, T.J. Żuchowski, Toruń 2004, s. 319-340.

Elliot James, The city in Maps urban mapping to 1900, London 1987.

Estreicher Karol, Bibliografia staropolska, t. 26, Kraków 1915.

Fabri Alessandro, Diversarum nationum ornatus oraz Additio ad duos superiores libros de habititus, Padova 1593

Filippi Elena, Bertelli Pietro, w: K. G. Saur, Allgemeines Künstlerlexikon, t. 10, Leipzig 1995 s. 50

Fonseca Cosimo Damiano, "Che tutto si stamperà in brieve tempo». Un Atlante di Città del Mezzogiorno progettato nel XVI secolo, w: http://www.lincei.it/files/documenti/ LectioBrevis_Fonseca_08-02-2013.pdf (dostęp: 19.06.2016).

Gulletta Maria Ida, Città 'ritratte' per un viaggio in Sicilia alla fine del XVI secolo (Disegni raccolti da P. Angelo Rocca, 1584), w: Viaggio in Sicilia: racconti, segni e città ritrovate. X Convegno di Studi di Sicilia Antica, Caltanissetta 10-11 maggio 2013, red. M. Congiu, C. Micciché, S. Modeo, Caltanissetta-Roma 2014, s. 351-376.

Grzebień Ludwik, Biblioteka biskupa Hieronima Rozrażewskiego (1542-1600), „Archiwa, Biblioteki i Muzea Kościelne”, 22 (1971) s. 61-168.

Kowalska Halina, Rozdrażewski Hieronim, w: Polski Stownik Biograficzny, t. 32, Kraków 1991, s. 355- 365. 
Kruft Hanno-Walter, Storia delle teorie architettoniche. D Vitruvio al Settecento, Roma 1999.

Laneri Maria Teresa, La Sardiniae brevis historia et descriptio, w: S. Arquer, Sardiniae brevis historia et descriptio, red. M. Laneri, Cagliari 2008, s. XCVII-CLXVII.

Le Piante di Roma, red A. P. Frutaz, Roma 1962.

Librowski Stanisław, Biskup Hieronim Rozrażewski jako humanista i mecenas, „Archiwa, Biblioteki i Muzea Kościelne", 11 (1965) s. 201-263.

Marabotto Maria Paola, In viaggio per conoscere, rappresentare e conserware ritratti di citta' nell „, Theatrum Urbium Italicarum”, w: C. Gambardella, Le Vie dei Mercanti. S.A.V.E. Heritage. Safeguard, of Architectural Visual, Environmental Heritage, vol. 1, Napoli 2011 (publikacja na CD dostępna również online: http://www.academia. edu/2335712/In_viaggio_per_conoscere_rappresentare_e_conservare._Ritratti_di citt $\%$ C3\%A0_nèl_Theatrum_Urbium_Itälicarum_Travel_to_learn_represent_and store._City_portraits_in_Theatrum_Urbium_Italicarum (dostęp: 19.06.2016).

Maggi Girolamo, Castriotto Jacomo, Delle fortificatione della Città (...) libri tre, Venetia 1564.

Mazzuchelli Giammaria, Gli Scrittori d'Italia, T. 2, Brescia 1760.

Miani Uluhogian Franca, Parma, i modi di vedere una cittá, Parma 1985.

Militello Pietro, Ritratti di città in Sicilia e a Malta (XVI-XVII secolo), Palermo 2008.

Muratore Nicoletta, Munafò Paola, Immagini di città raccolte da un frate agostiniano alla fine del XVI secolo, Roma 1991.

Nierzwicki Krzysztof, Biblioteki Kartuzji Kaszubskiej oraz jej konwentów filialnych w Berezie Kartuskiej i Gidlach, Pelplin 2001.

Pawlicki Maciej, Związki geometryczne XVII-wiecznych widoków miast z ich rzeczywistym rozplanowaniem, „Teka Komisji Urbanistyki i Architektury”, 7 (1973) s. 161173.

Pilz Kurt, Hirschvogel Augustin, w: Neue Deutsche Biographie, Band 9, Berlin 1972, s. 231-232.

Polkowski Ignacy, Jeszcze o testamencie biskupa Hieronima Rozrażewskiego, „Przegląd Katolicki”, 22 (1884) s. 473-374.

Popham Arthur Ewart, George Hoefnagel and the Civitates Orbis Terrarum, „Maso Finiguera", 1 (1936) s. 120-180.

Porcacchi Tomasso, L'isole piu famose del mondo, Venetia 1590

Puppi Lionello, Universo Mario, Le citta nella storia d'Italia. Padova, Bari 1982.

Saccomani Elisabetta, Il paesaggio nel disegno veneziano delia prima meta del Cinquecento: $i$ disegni da collezione, w: Pejzaż-narodziny gatunku 1400-1600, Materiaty sesji naukowej 23-24 X 2003, red. S. Dudzik, T.J. Żuchowski, Toruń 2004,s. 201-216.

Schedel Hartman, Liber Cronicarum, Nürnberg 1493.

Schmitt Annegrit, Hanns Lautensack, w: Neue Deutsche Biographie, Band 13, Berlin 1982, s. 729.

Schultz Juergen, The printed plans and Panoramic Vievs of Venice (1486-1797), Firenze 1970.

Schultz Juergen, Jacopo de'Barbari's view of Venice: map making, city views and moralized geography before the year 1500, „Art Bulletin”, 9 (1978) s. 425-474.

Scolari Stefano, Paolo Forlani. w: http://www.mapforum.com/11/11issue.html (dostęp: 20.07.2007).

Stella Aldo, Arquer Sigismondo, w: Dizionario Biografico degli Italiani, vol. 4, Roma 1962, s. 302-304. 
Testamentum olim reverendissimi domini Hieronymi comitis a Rozrażov, episcopi Wladislaviensis, w: Monumenta historica dioeceseos Wladislaviensis, t. 2, Wladislaviae 1882.

Tooley Ronald Vere, Maps in italian Atlases of the Sixtenth Century, „Imago Mundi”, 3 (1939) s. 12-47.

Ulewicz Tadeusz, Iter Romano-Italicum Polonorum. czyli o zwiazkach umystowo-kulturalnych Polski z Włochami w wiekach średnich i renesansie, Kraków 1999.

Valente Giuseppina, L'itinerario d'Italia di Franz Schott: un prototipo seicentesco della guida per il viaggio in Italia, w: F. Schott, Itinerario overo descriitione de' viaggi principali in Italia, Padova [reprint wydania 1670 roku], Edizioni CISVA 2009, s . III-XXVIII.

Vallegio (Valesio) Francesco, Raccolta di li più illustri et famose città di tutto il mondo, Venetiis bd.

Vasari Giorgio, Żywoty najsławniejszych malarzy, rzeźbiarzy i architektów, oprac. i thum. K. Estreicher, t. 4, Warszawa-Kraków 1985.

Visceglia Maria Antonietta, Il viaggio ceremoniale di Carlo V dopo Tunisi, w: Dimensioni e problemi della ricerca storica, Roma 2001.

Zappella Giuseppina, Le marche dei tipografi e degli editori italiani del Cinquecento, t. 1, Milano 1986.

\section{THEATRUM URBIUM ITALICARUM PIETRA BERTELLEGO - PRZEDSIEWZIECIE WYDAWNICZE BISKUPA HIERONIMA ROZRAŻEW- SKIEGO PODCZAS JEGO PODRÓŻY DO RZYMU}

\section{Streszczenie}

Z końcem 1599 r. w Wenecji ukazała się bogato ilustrowana książka Theatrum urbium Italicarum. Jej autorem oraz wydawcą był padewski drukarz i rytownik - Pietro Bertelli. Zgodnie $\mathrm{z}$ informacjami zawartymi we frontyspisie oraz tekście dedykacyjnym dzieło to ofiarowane zostało biskupowi kujawsko-pomorskiemu Hieronimowi Rozrażewskiemu (1542-1600). Niniejszy artykuł poświęcony jest kilku zasadniczym kwestiom związanym z powstaniem i oddziaływaniem tego wydawnictwa. W pierwszym rzędzie przybliżony został krąg bezpośrednich twórców książki: wydawcy Pietra Bertellego oraz dających się zidentyfikować twórców poszczególnych rycin (Jacoppo Monticolo, Francesco Bertelli). Następnie omówiona została typologia przedstawień miast, ich pierwowzory ikonograficzne i bezpośrednia proweniencja. Wskazanie tej ostatniej w powiązaniu z udowodnieniem realnego wpływu publikacji Bertellego na materiał ilustracyjny szeregu późniejszych przedsięwzięć wydawniczych, pozwolił określić znaczenie Theatrum w rozwoju nowożytnej książkowej weduty. Osobne omówienie znalazł w tekście problem okoliczności powstania książki oraz udział w całym przedsięwzięciu polskiego hierarchy.

Słowa kluczowe: biskup Hieronim Rozrażewski; Bertelli Pietro; grafika książkowa XVI wiek; weduta; widoki miast włoskich; ikonografia miast włoskich; Theatrum urbium Italicarum; Jacopo Monticolo 


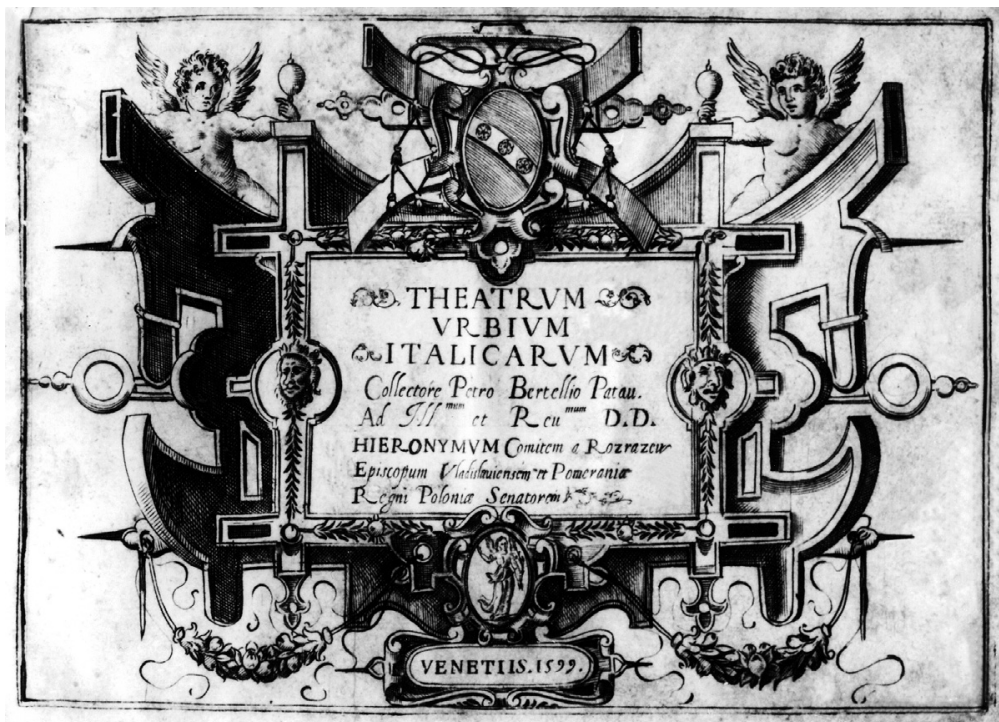

il. 1. P. Bertelli, Frontyspis książki Theatrum urbium italicarum, Wenecja 1599.

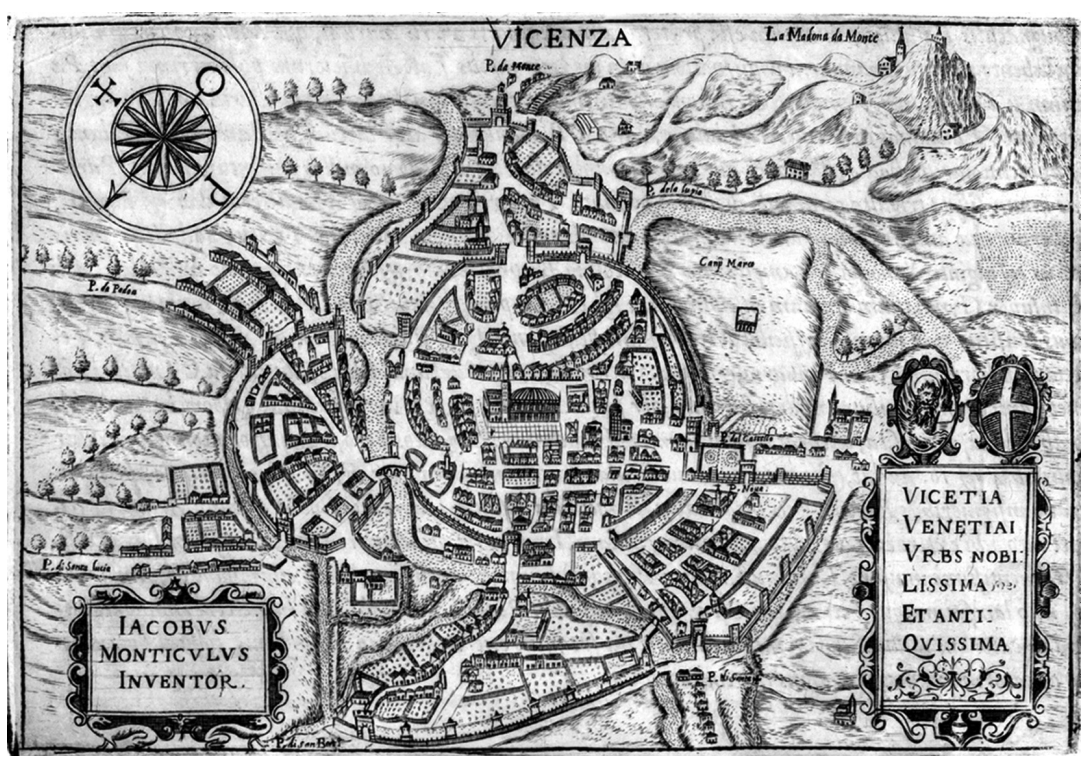

i1. 2. Widok Vicenzy ilustracja z P. Bertelli, Theatrum..., k. 61 v. 


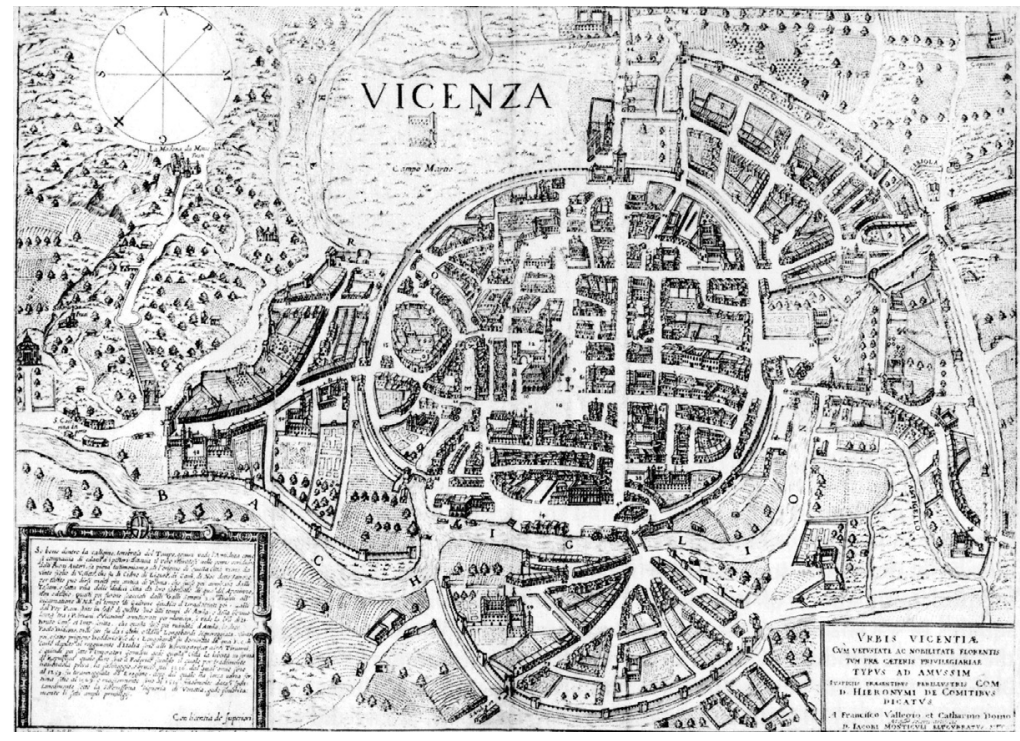

il. 3. Jacopo Monticolo, Vicenza, 1611, miedzioryt.

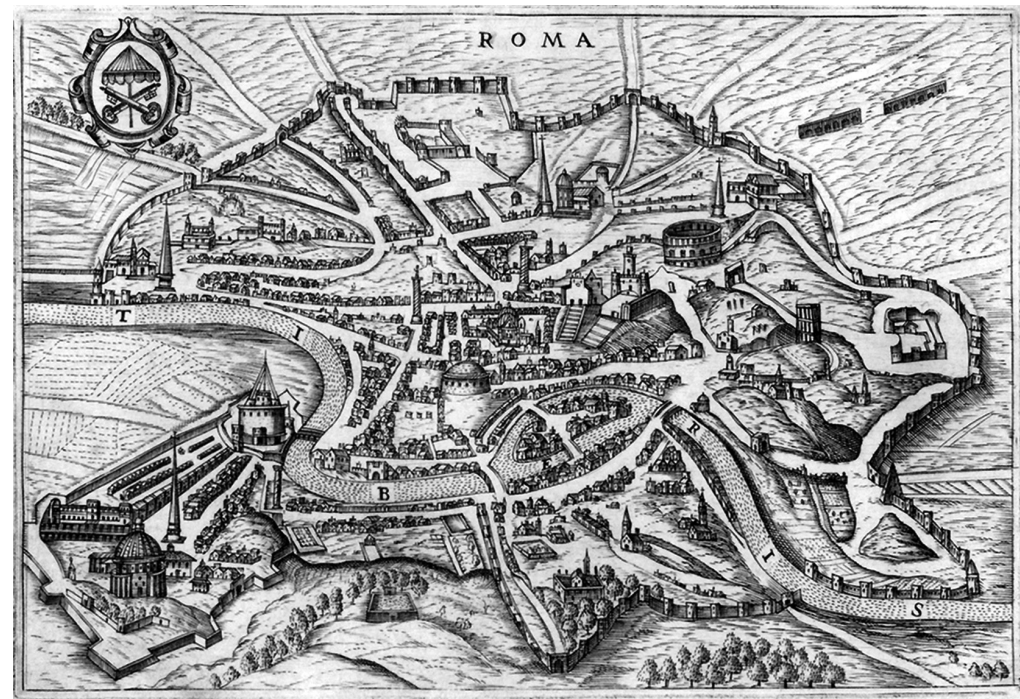

il. 4. Widok Rzymu, ilustracja z P. Bertelli, Theatrum..., k. 1 r. 


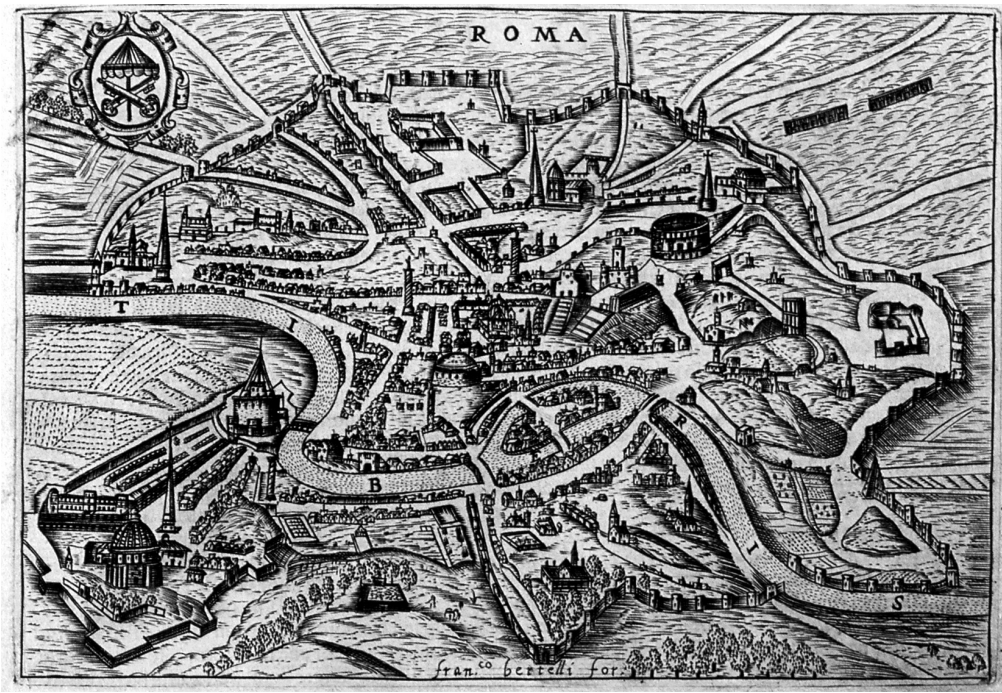

il. 5.Francesco Bertelli, Roma, 1599 miedzioryt, wym. 120×175 mm, The Getty Library, sygn. P 850002. (fot. Getty Archiv.)

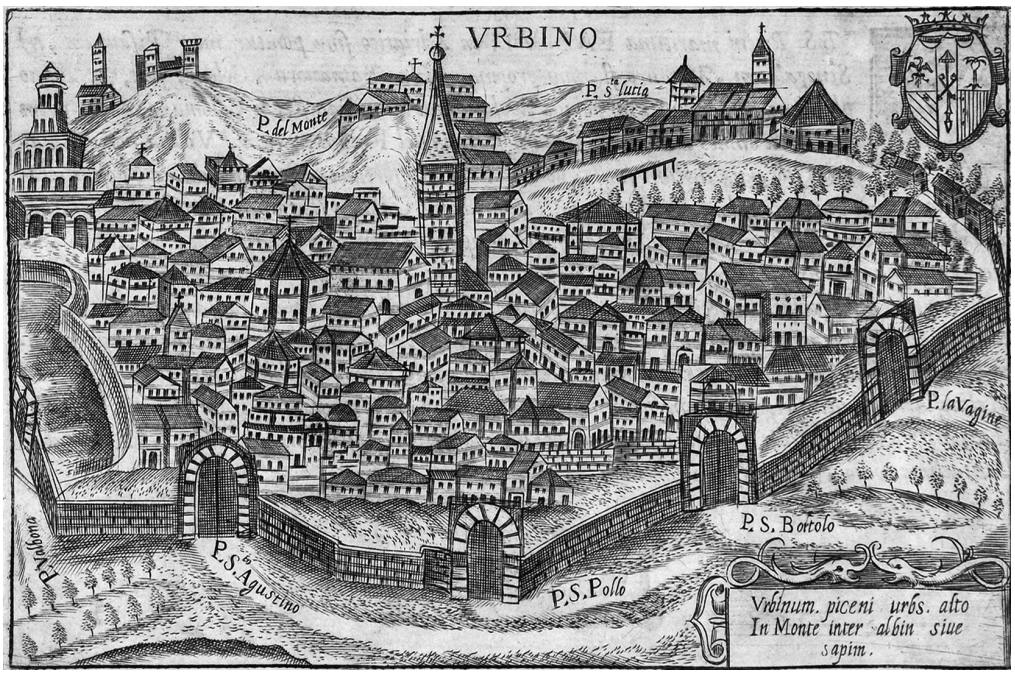

il. 6. Widok Urbino, ilustracja z P. Bertelli, Theatrum..., k. 51 v. 


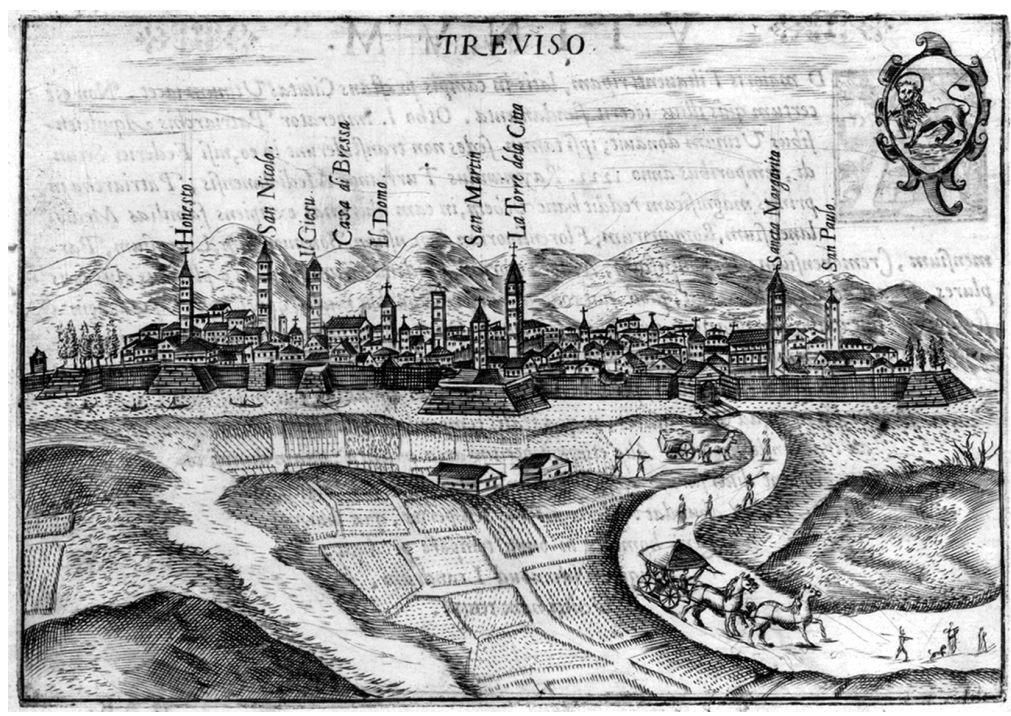

il. 7. Widok Treviso, ilustracja z P. Bertelli, Theatrum..., k. 54 v.

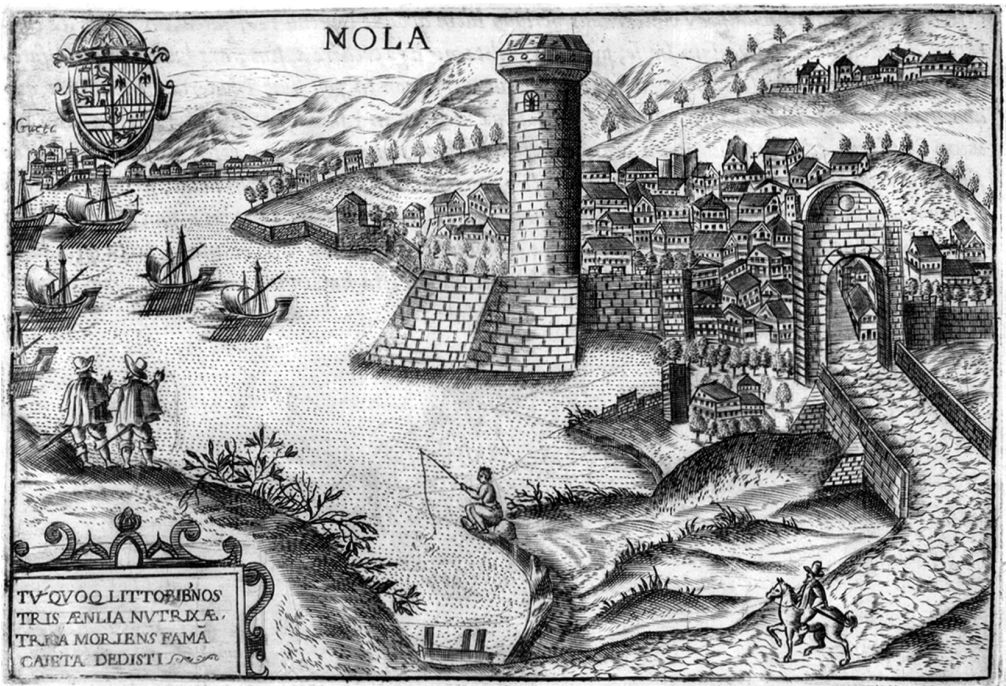

il. 8. Widok Moli, ilustracja z P. Bertelli, Theatrum..., k. 77 v. 


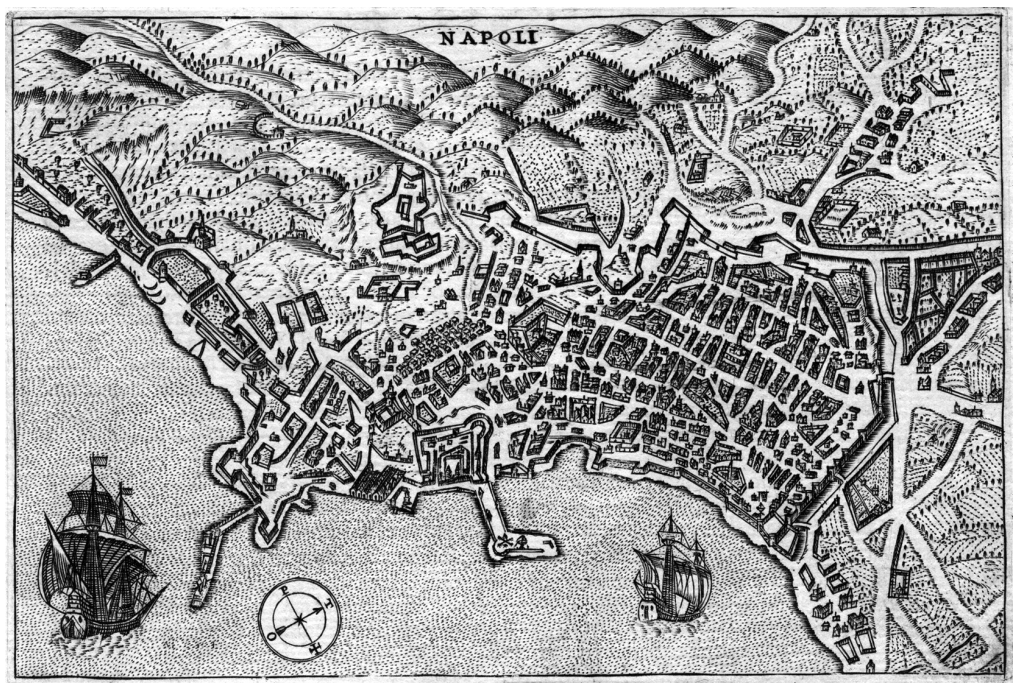

il. 9. Widok Neapolu, ilustracja z P. Bertelli, Theatrum..., k. 4 v.

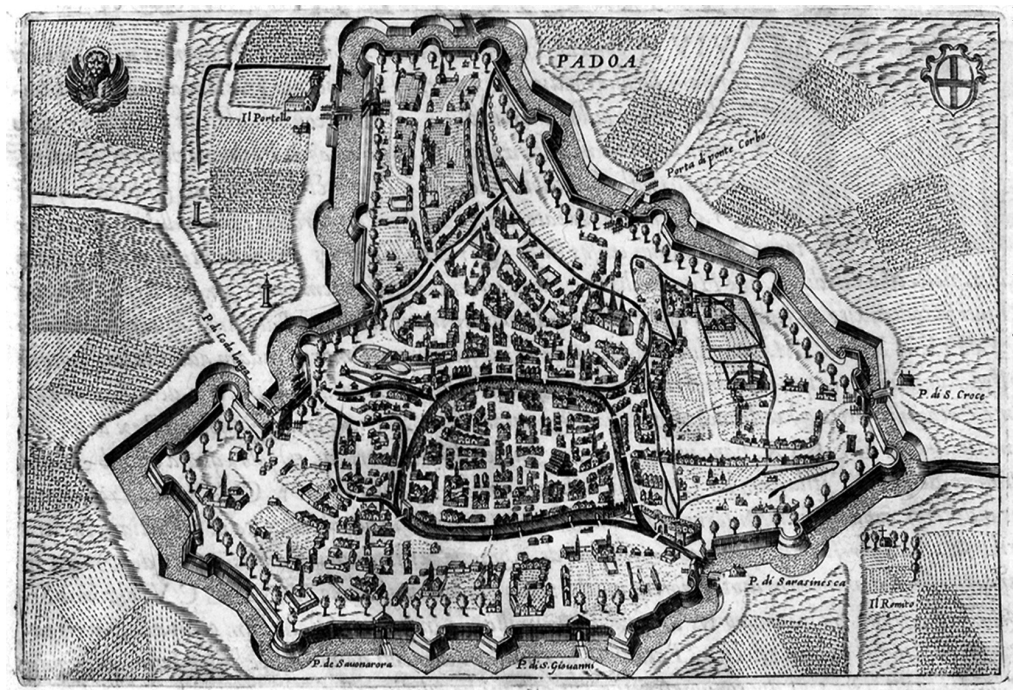

il. 10. Widok Padwy, ilustracja z P. Bertelli, Theatrum..., k. 60 r. 


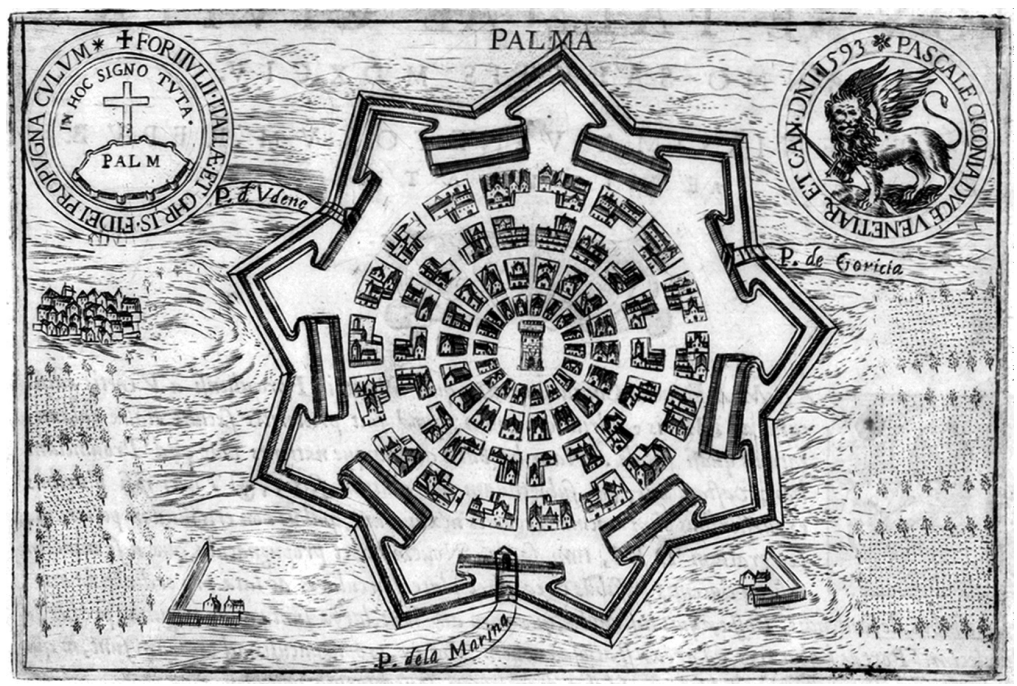

il. 11. Widok Palma Nuova, ilustracja z P. Bertelli, Theatrum..., k. 56 r.

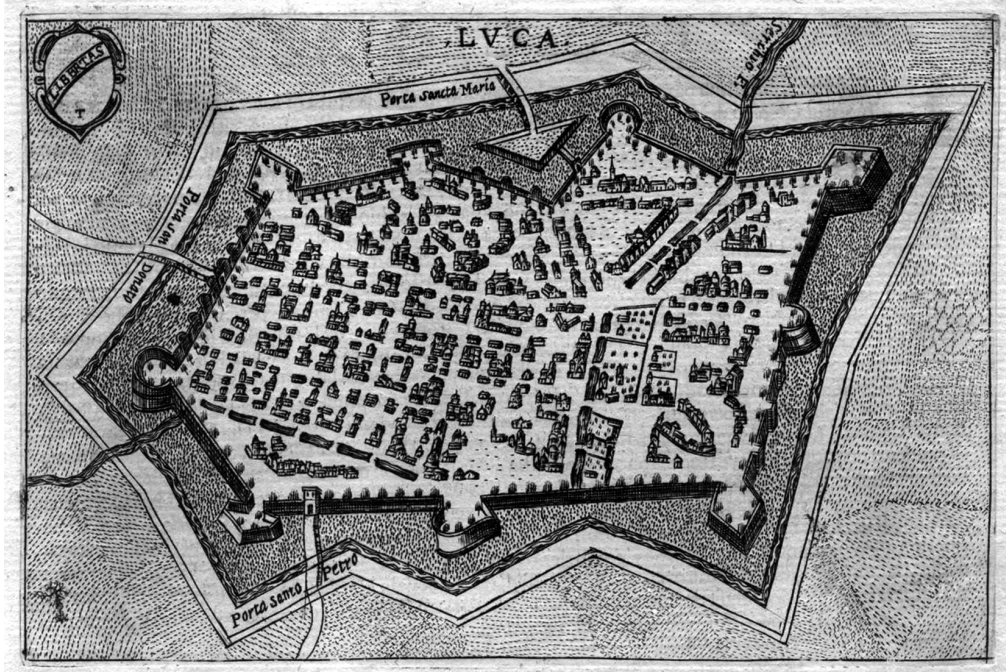

il. 12. Widok Lukki, ilustracja z P. Bertelli, Theatrum..., k. 37 v. 


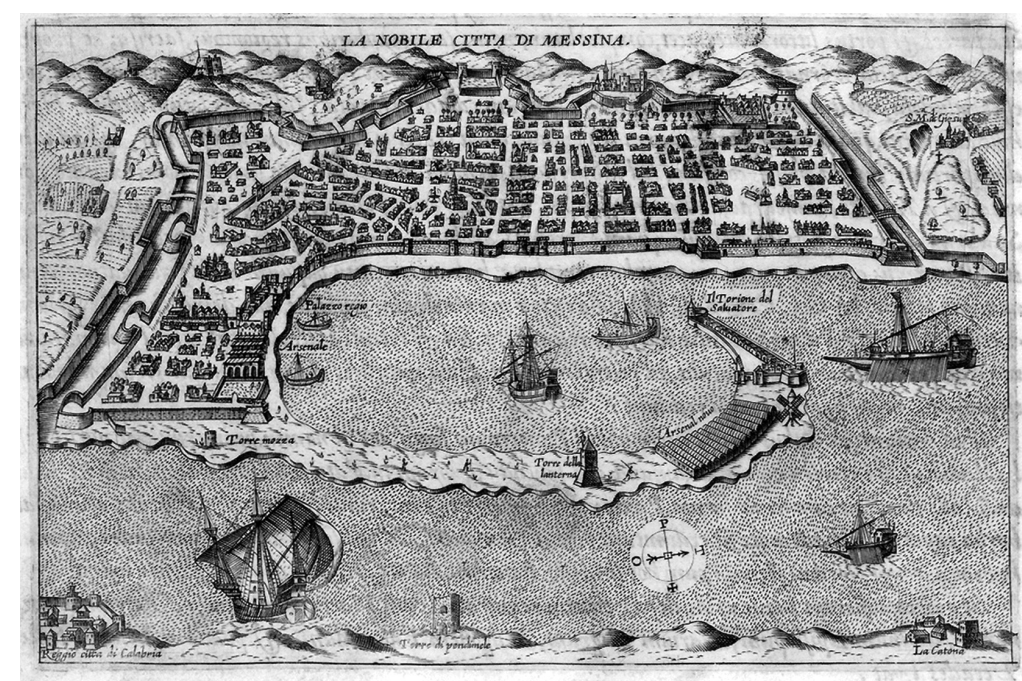

i1. 13. Widok Messyny, ilustracja z P. Bertelli, Theatrum..., k. 11 v.

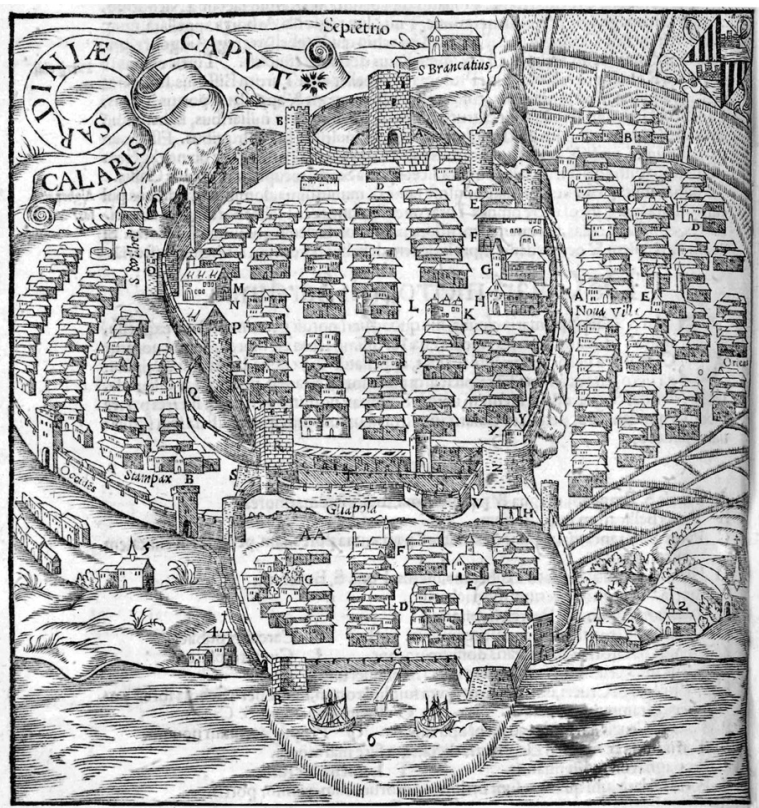

il. 14. Widok Cagliari, ilustracja z S. Münster, Cosmographia... Basilea 1550, s. 248. 


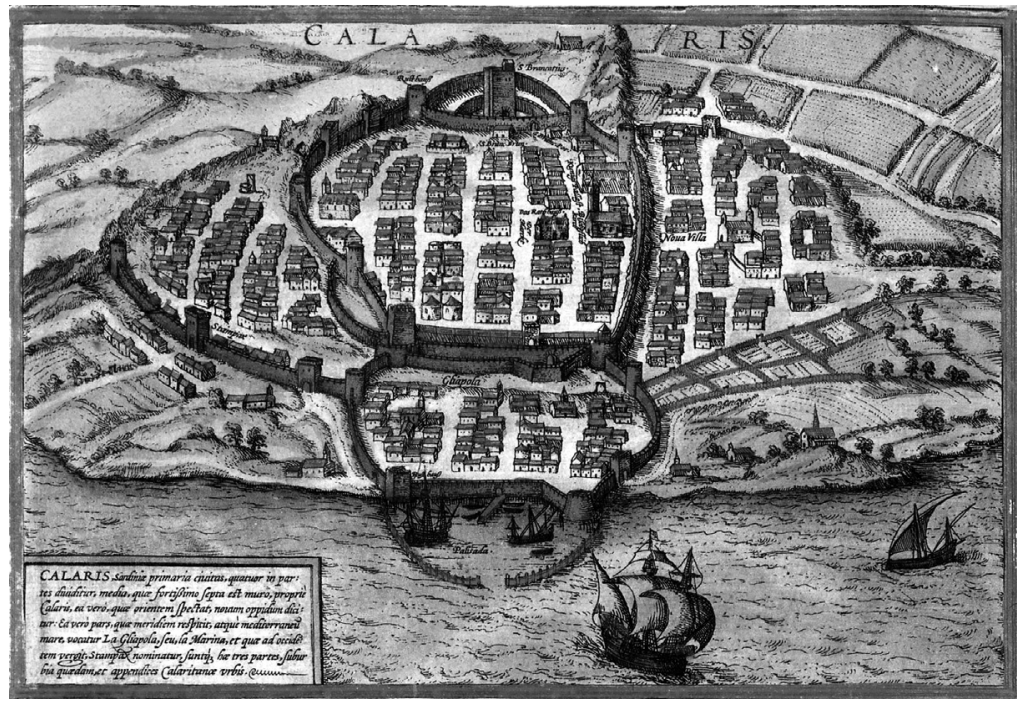

il. 15. Widok Cagliari, ilustracja z G. Braun, F. Hogenberg, Civitates..., t. I, Coloniae 1572, k. 50 r.

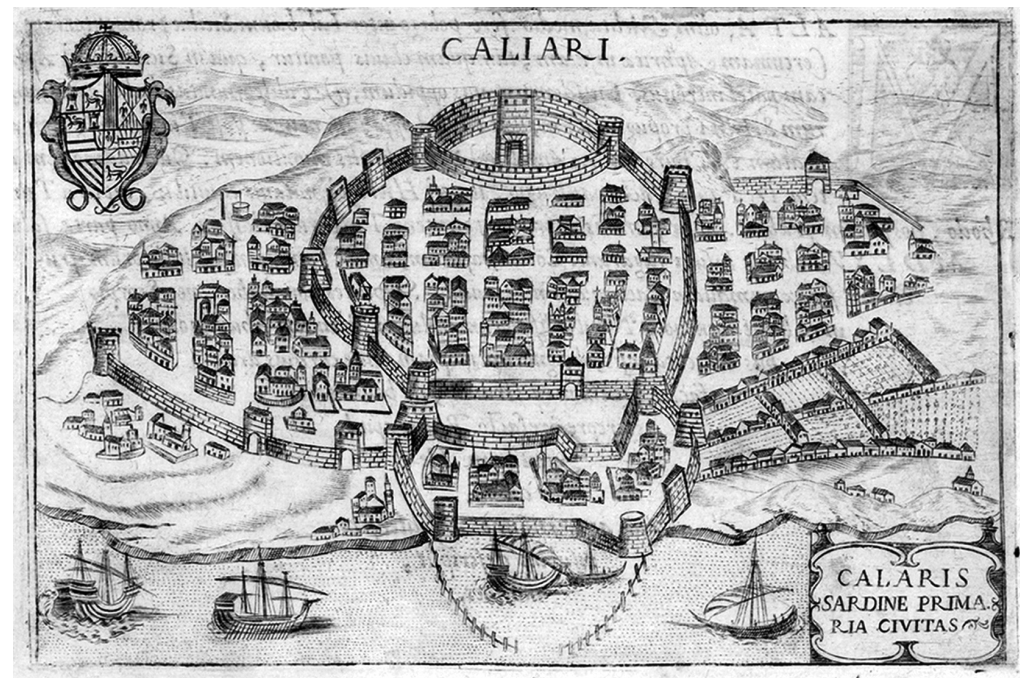

il. 16. Cagliari, ilustracja z P. Bertelli, Theatrum..., k. 22 v. 


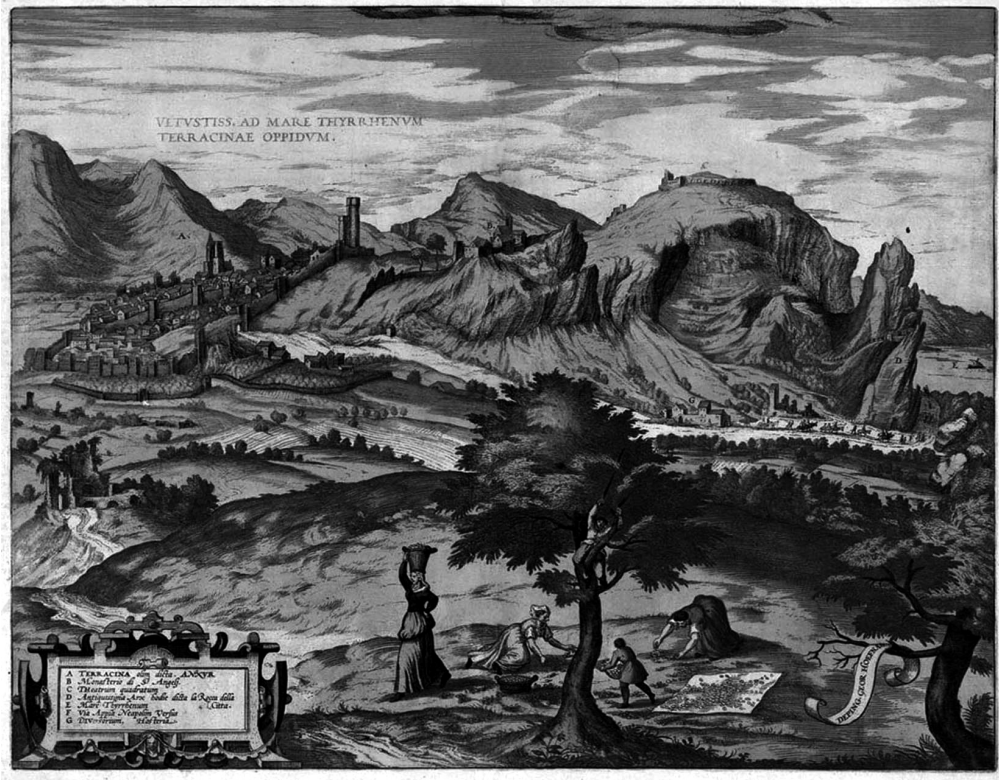

il. 17. Widok Terraciny, ilustracja z G. Braun, F. Hogenberg, Civitates..., t. III, Coloniae 1581, k. 265 r.

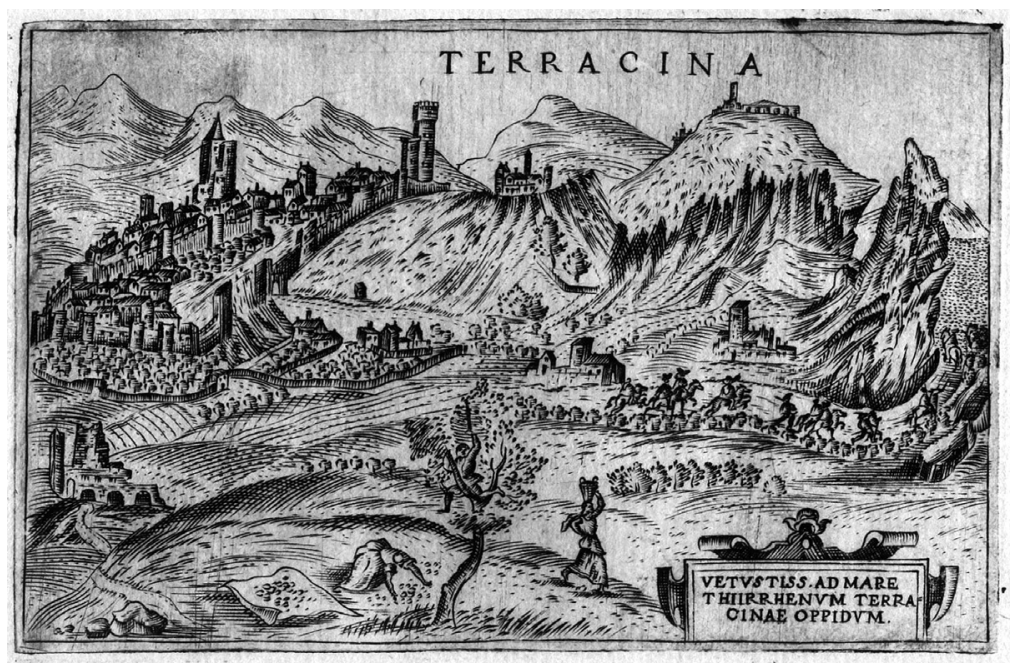

il. 18. Widok Terraciny, ilustracja z F. Valegio, Raccolta..., k. 57 v. 


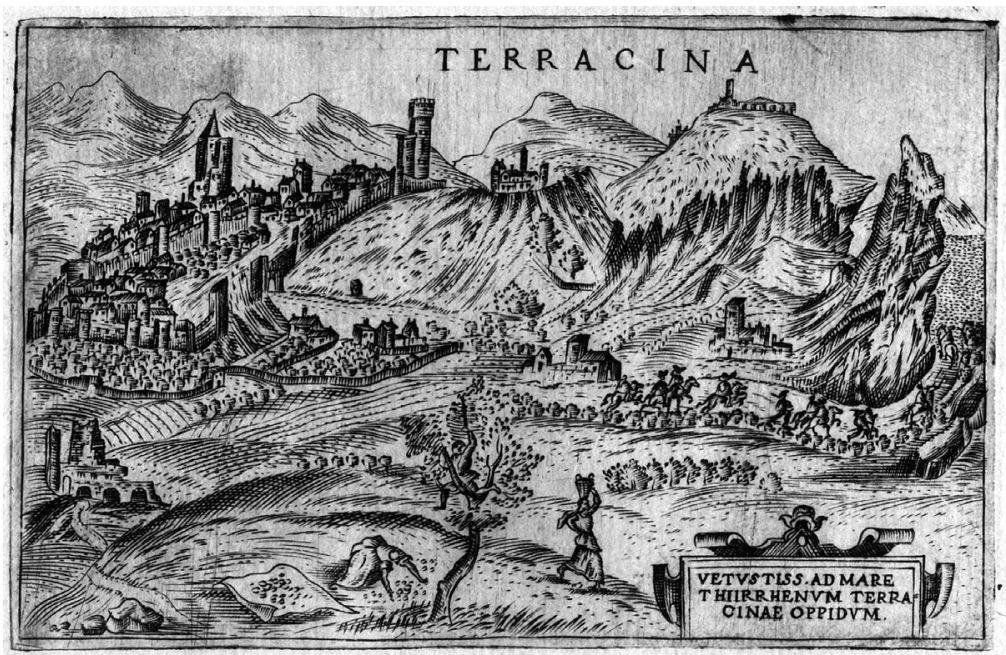

il. 19. Widok Terraciny, ilustracja z P. Bertelli, Theatrum..., k. 86 v.

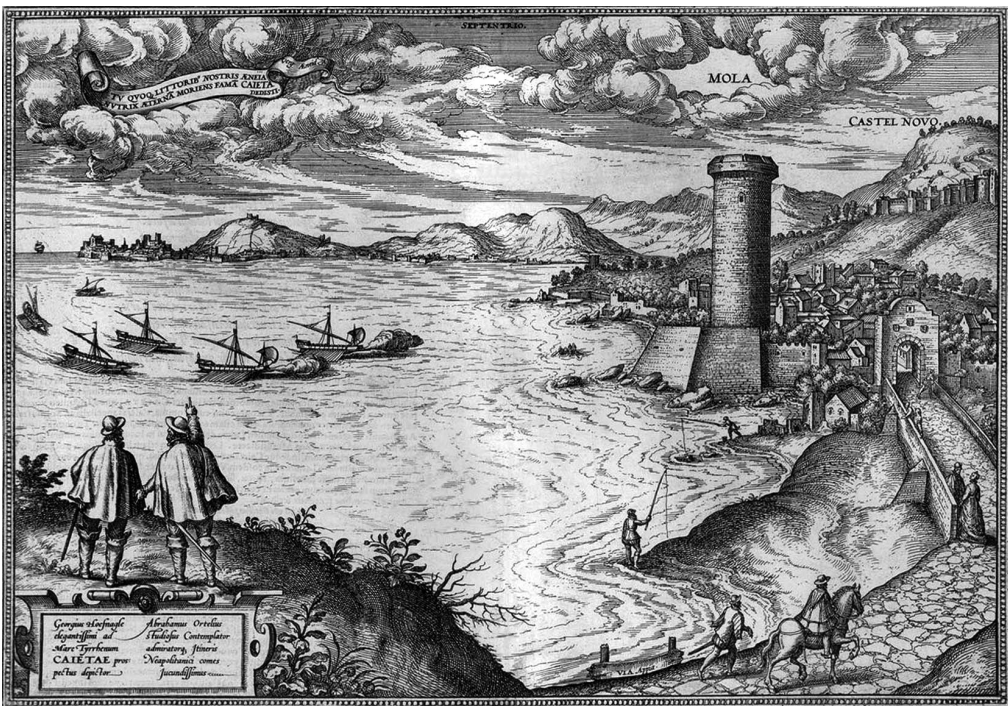

il. 20. Widok Moli, ilustracja z G. Braun, F. Hogenberg, Civitates..., t. V, Coloniae 1598, k. 50 


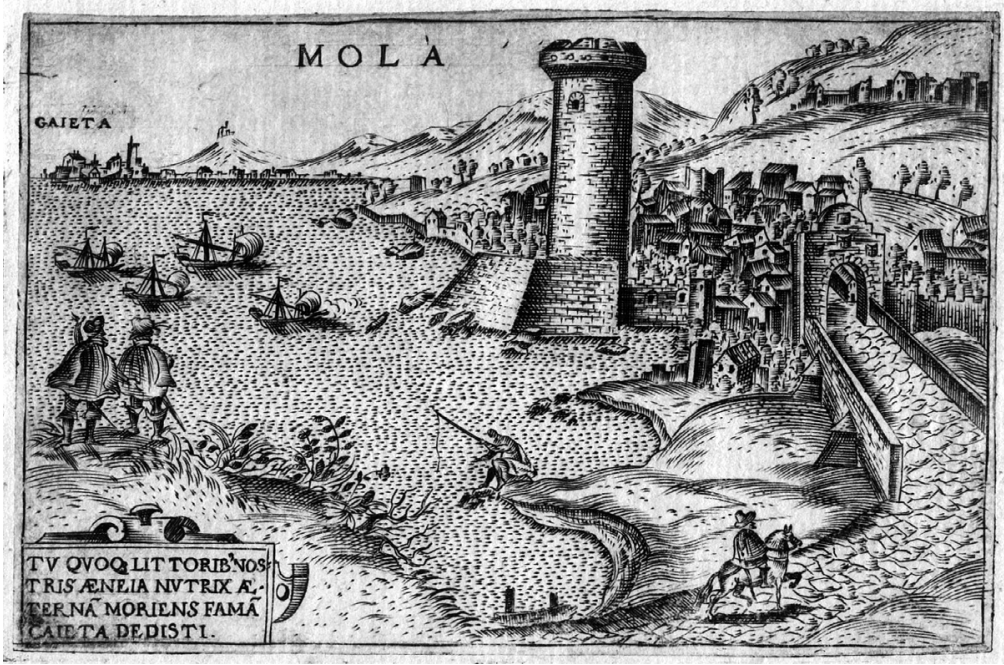

il. 21. Widok Moli, ilustracja z F. Valegio, Racolta..., k. 60 r.

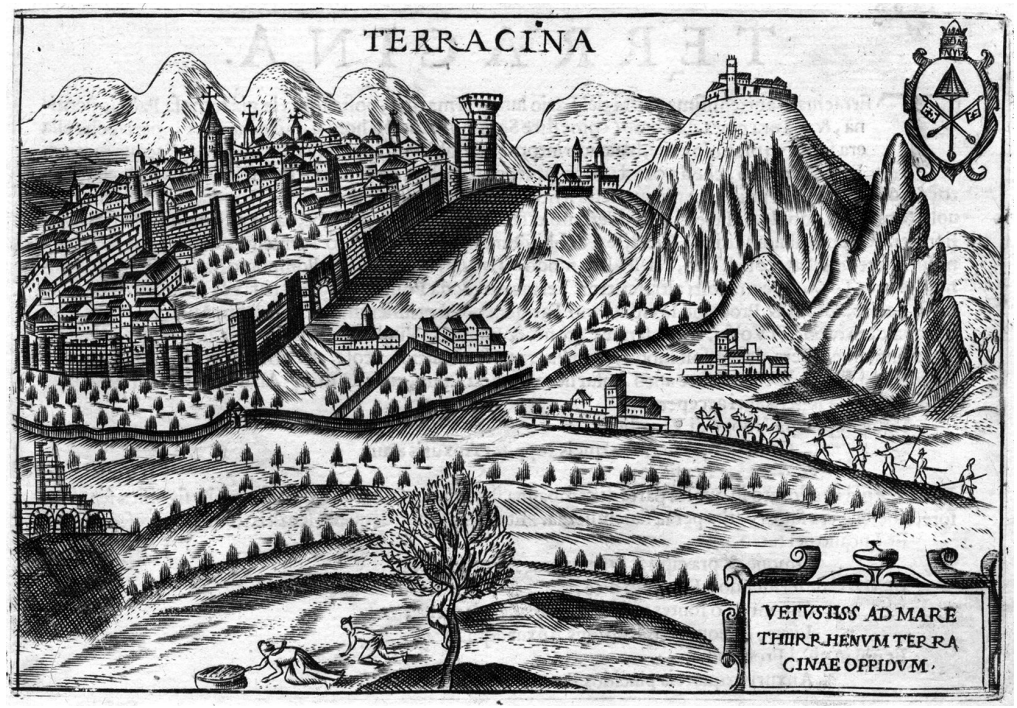

il. 22. Widok Terraciny, ilustracja z F. Bertelli, Aggiunta al Teatro..., Padova 1629, k. 86 v 


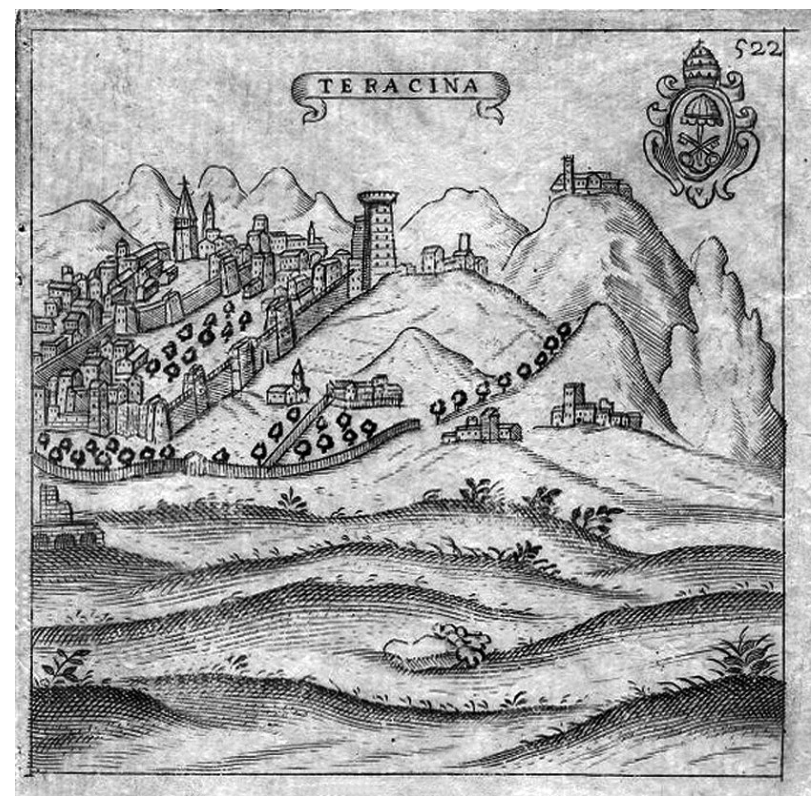

il. 23. Widok Terraciny, ilustracja z F. Scotto, Itinerario..., Padova 1669.

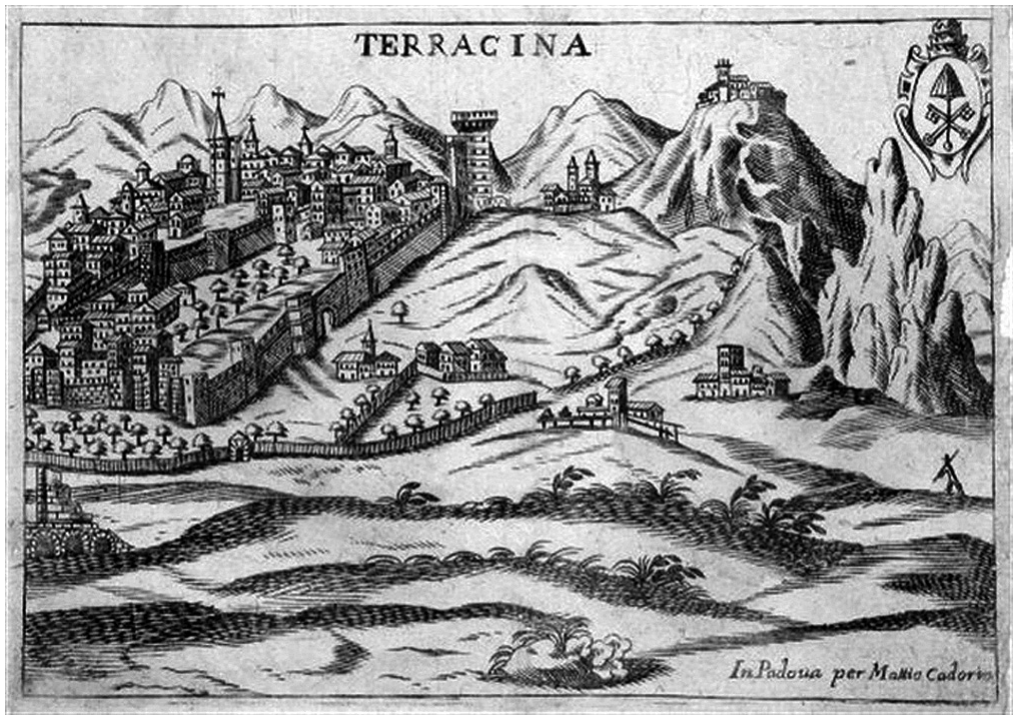

il. 24. Widok Terraciny, ilustracja z F. Scotto, Itinerario..., Padova 1670. 


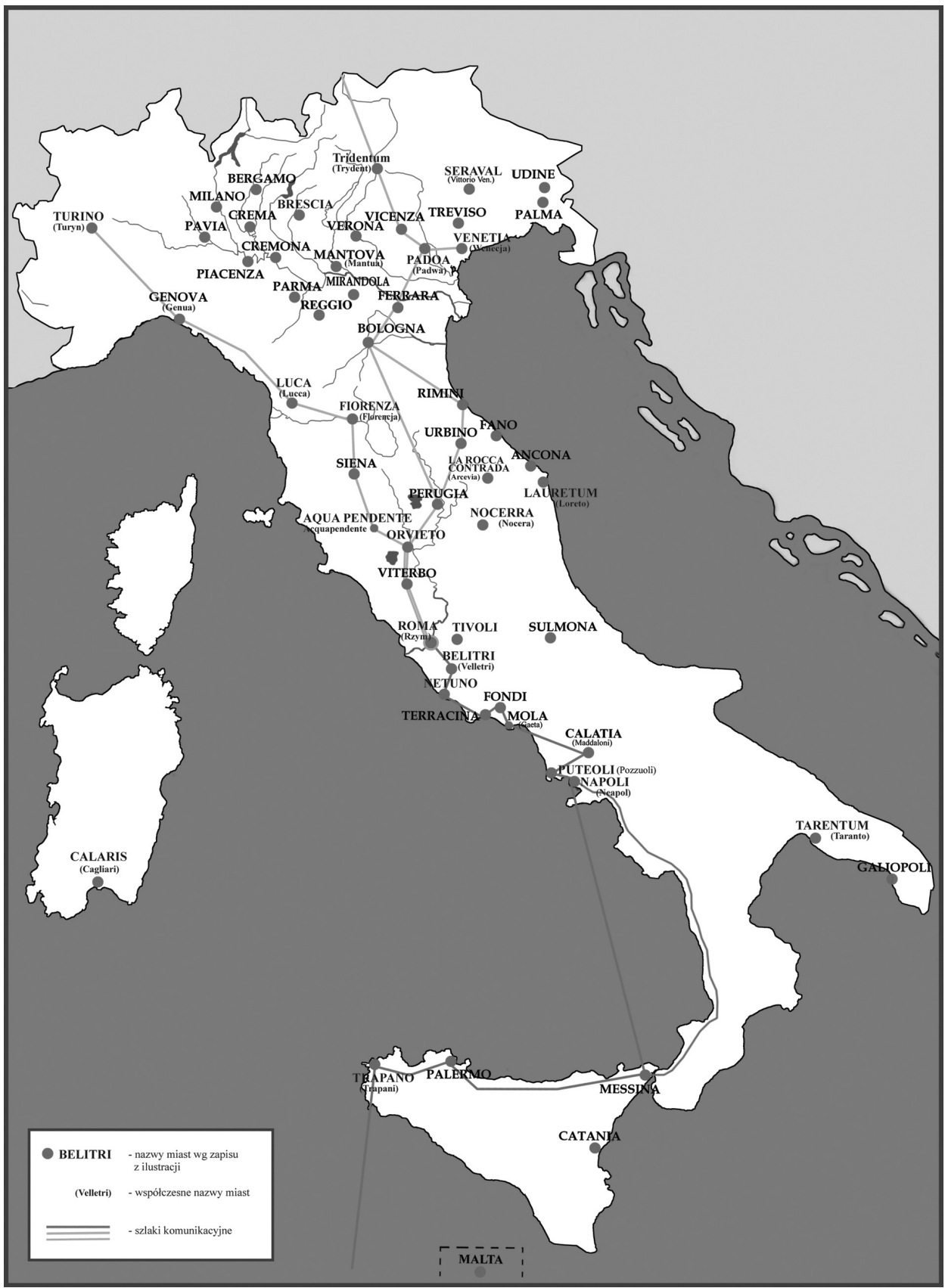

ryc. 1. Topograficzny rozkład miast w Theatrum... 


\title{
THEATRUM URBIUM ITALICARUM BY PIETRO BERTELLI - BISHOP HIERONIM ROZRAŻEWSKI'S PUBLISHING UNDERTAKING DURING HIS VISITS TO ROME
}

\begin{abstract}
Summary
At the end of 1599, a richly illustrated book Theatrum urbium Italicarum appeared in Venice. The author and publisher was a printer and engraver of Padua - Pietro Bertelli. According to the information provided on the front page and the dedication text, the work was donated to the bishop of Kujawy and Pomorze, Hieronim Rozrażewski (1542-1600). The following article is devoted to several key issues related to the release and influence of this publication. First, the paper focuses on the direct creators of the book: the publisher Pietro Bertelli and the identifiable creators of the various prints (Jacopo Monticolo, Francesco Bertelli). Then it presents the typology of the town depictions, their iconographic representations and direct provenance. Establishing their origins and linking them with the real influence of Bertelli's publication on the illustration material of a number of later publishing undertakings allowed for determining Theatrum's importance in the development of a modern veduta. The text also discusses the problem of the origins of the book and the Polish hierarch's involvement in this entire undertaking.

Keywords: Bishop Hieronim Rozrażewski; Bertelli Pietro; the 16th-century book design; a veduta; the images of Italian towns; the iconography of Italian towns; Theatrum urbium Italicarum; Jacopo Monticolo
\end{abstract}

